\title{
Marsh foraminifera in the Bay of Fundy: modern distribution and application to sea-level determinations
}

\author{
D.A. Smith, D.B. Scott and F.S. Medioli \\ Centre for Marine Geology, Dalhousie University, Halifax, N.S. B3H 325 \\ Publication No. 17, Centre for Marine Geology, Dalhousie University
}

\begin{abstract}
Although marsh foraminiferal zonations are comparatively well known for most of Atlantic Canada, data from the vertically expanded marsh zones in the Bay of Fundy are insufficient for marsh foraminiferal zonations that can be used to accurately determine former sea levels. In this paper we present data from two well-documented surface transects that illustrate vertical ranges of marsh foraminifera in the Bay of Fundy. Trochammina inflata characterizes the highest margin with a zone la of $20 \mathrm{~cm}$ vertical range. Tiphotrocha comprimata together with $T$. inflata comprise zone Ib (vertical range $75 \mathrm{~cm}$ ) while Miliammina fusca and other low marsh species characterize zone II faunas (vertical range $450 \mathrm{~cm}$ ). As in Atlantic marshes the fauna nearest the higher high water level produces the best accuracy for relocating former sea levels while low marsh (zone II) is not a good indicator.
\end{abstract}

Using marsh foraminiferal zonations and the tidal amplicication curve developed in earlier work, it is now possible to accurately determine former sea levels in the Bay of Fundy, at least for the last 4000 years.

Même si l'on connaît assez bien la zonation des foraminifères de marais pour la plus grande partie de la côte atlantique du Canada, le manque de données sur le dévelopment vertical des zones de marais nous empêche d'établir avec exactitude les niveaux marins passés. Dans cet article, nous présentons des données provenant de deux traverses bien documentées, qui illustrent les étendues verticales des foraminifères de marais dans la Baie de Fundy. Trochammina inflata charactérise la limite supérieure par une zone la d'une étendue verticale de $20 \mathrm{~cm}$. Tiphotrocha comprimata ainsi que $T$. inflata embrassent la zone Ib (êtendue verticale de $75 \mathrm{~cm}$ ) cependant que Miliammina fusca et d'autres espèces de bas-marais charactérisent les faunes de la zone II (étendue verticale de $450 \mathrm{~cm}$ ). Comme dans les marais atlantiques, la faune la plus près du plus haut niveau de marêe haute procure la meilleure exactitude pour situer. les niveaux marins antérieurs alors que la zone de bas-marais (zone II) n'est pas un bon indice.

L'utilization des zonations de foraminifères de marais et de la courbe d'amplification de marée développée lors de travaux antérieurs permet donc de déterminer avec exactitude, à tout le moins pour les derniers 4000 ans, les niveaux marins passés dans le Baie de Fundy.

[Traduit par le journal]

\section{INTRODUCTION}

The relationship of marsh foraminiferal zonations to elevation above mean sea level (a.m.s.l.) has been well established world-wide for most types of tidal regimes (Scott and Medioli 1980a). This work has shown that marsh foraminiferal zonations can relocate former sea levels to within \pm 5 $\mathrm{cm}$ in normal $(2-4 \mathrm{~m})$ tidal regimes. However, Scott and Medioli (1980a) were unable to completely document how these zonations responded to the extreme tidal ranges found in the Bay of Fundy. In this study, we have obtained two representative surface transects from Kingsport marsh (Fig. 1) which will document the vertical limits of marsh foraminiferal zonations in an extreme tidal range $(16 \mathrm{~m})$. Grant (1970) suggested that rates MARITIME SEDIMENTS AND ATLANTIC GEOLOGY 20, 127-142 (1984) of apparent sea-level rise in the Bay of Fundy (as measured by higher-high water [HHW] indicators) was approximately one-half relative sea-level movement and one-half tidal amplification (i.e. part of apparent rise movement of the HHW marker took place without a change in mean sea level [MSL]). However, Scott and Greenberg (1983) have shown that by 4000 years before present (ybp) tidal amplification was over $80 \%$ complete in the Minas Basin and that tidal amplification was a relatively small component of relative sea-level rise records determined using HHW markers. Hence it is possible to determine accurate relative sea-level curves from the inner Bay of Fundy for the last 4000 years using $\mathrm{HHW}$ indicators (i.e. marsh foraminiferal zonations). Using the calculations of Scott and Greenberg (1983), small corrections can be 
applied to the data to give more exact values of relative sea-level rise.

In this paper, we first illustrate that the vertical zonations of marsh foraminifera do provide an accurate means of determining former sea levels in an expanded tidal system, and then we apply these data to some drill hole sites at four locations around the inner Bay of Fundy.

\section{Previous Work}

Grant (1970) provided limited information on rates of sea-level rise in the Bay of Fundy because his data points were poorly constrained. Since then, Scott (1977), Scott and Medioli (1978, 1980a,b) and Scott et al. (1981), have demonstrated the close relationship of marsh foraminifera to sea level in several areas of Atlantic Canada, and provided a means of obtaining reliable data.

Deonarine (1979) examined some material for foraminifera from a marsh site inside the Bay of Fundy but had no data on elevation. However the species were similar to those observed in other Atlantic marshes.

\section{Methods}

Surficial sediment samples were collected along two transects from Kingsport marsh at low tide together with environmental data (vegetation cover, elevation and salinities). Replicate samples of $10 \mathrm{~cm}^{3}\left(10 \mathrm{~cm}^{2} \times 1\right.$ $\mathrm{cm}$ ) were obtained at each station along the transects, using a stainless steel hand-held corer (Scott 1977).

Subsurface coring was conducted at Kingsport and three other marshes in the Bay of Fundy (Ft. Beausejour, Mary's Point and Granville Ferry, Figure 1). The cores were obtained using a Davis peat corer which was forced down to the deepest peat layer and a trigger was released on the corer, enabling retrieval of a small

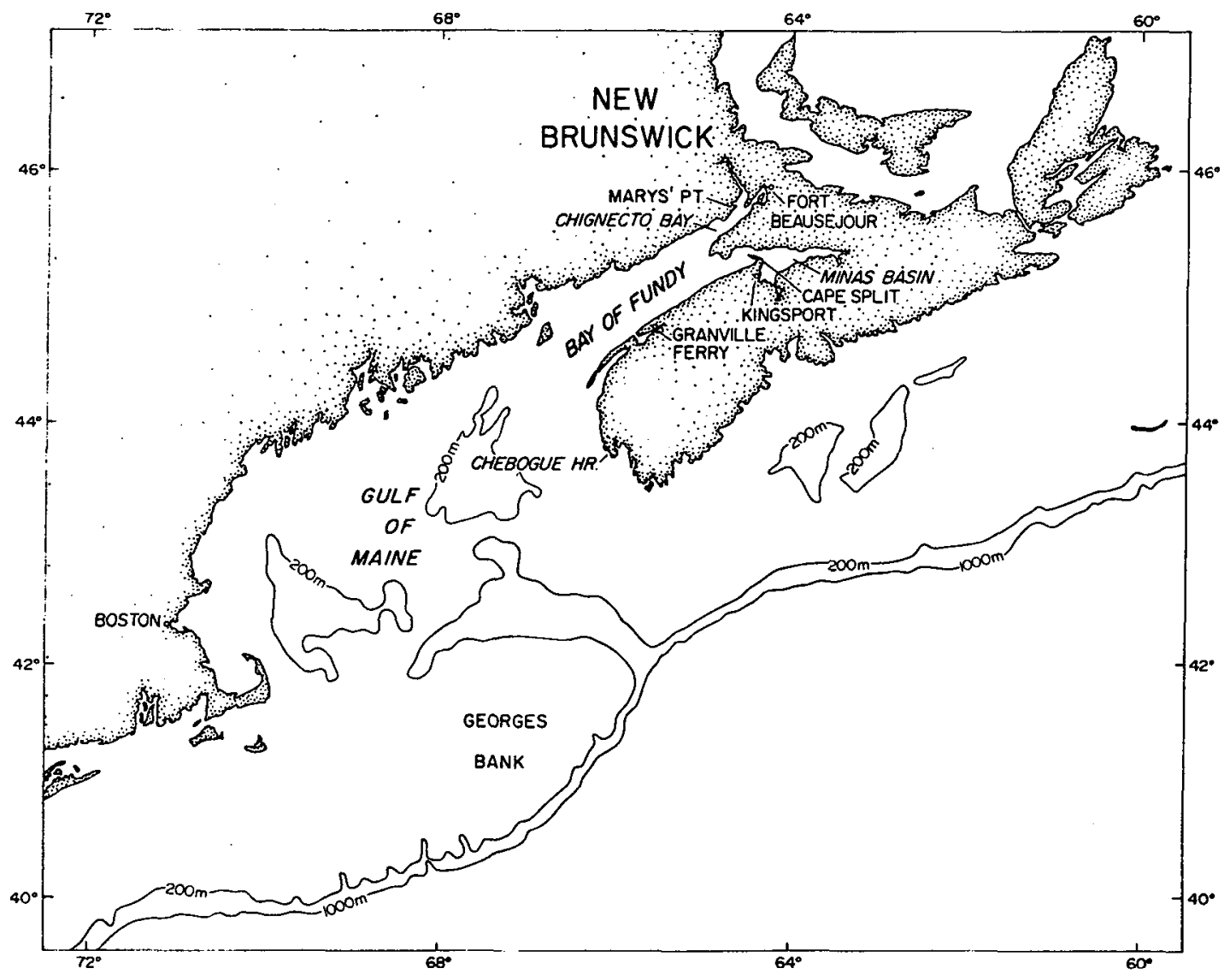

Fig. 1 - Regional map with study locations indicated. 
test core. Exploratory testing was done to find the thickest peat sequence. A series of cores were obtained at each marsh to construct apparent relative sea-level curves (Scott and Greenberg 1983) based on basal peat deposits.

Surficial sediment samples were wet sieved through $0.5 \mathrm{~mm}$ and $0.063 \mathrm{~mm}$ sieves, the $0.5 \mathrm{~mm}$ sieve retaining coarse organics and the $0.63 \mathrm{~mm}$ sieve retaining the foraminifera. Organics remaining in the sample at this point were removed by decantation with water. The samples were then fixed in $10 \%$ formalin and Rose Bengal. After washing off excess formalin and Rose Bengal, the samples were placed in denatured alcohol for preservation. Several samples contained large amounts of sand which was separated from foraminifera by floating the foraminifera in $\mathrm{CCL}_{4}$. The core samples were treated in a similar manner, except no formalin or Rose Bengal was used.

The salinities at sample stations were determined at the time of sample collection by squeezing pore water out of the sediment onto an American Optical Salinity refractometer (compensated for temperature variance, accuracy \pm lo/oo). The elevation at each station was obtained using a transit and stadial rod and referenced to nearby bench marks.

$\mathrm{C}^{14}$ dates were obtained from material in the deepest layers of peat at each core location; the dated levels were resting on noncompatible substrates to avoid autocompaction of peat (Kaye and Barghorn 1964).

Photographs of gold-palladium coated specimens were taken using the Cambridge (180) scanning electron microscope (located at Bedford Institute of Oceanography) with Polaroid N/P 55 film.

\section{Results}

Vegetation and Salinity: The plant species present at Kingsport Marsh are similar in their spatial distribution

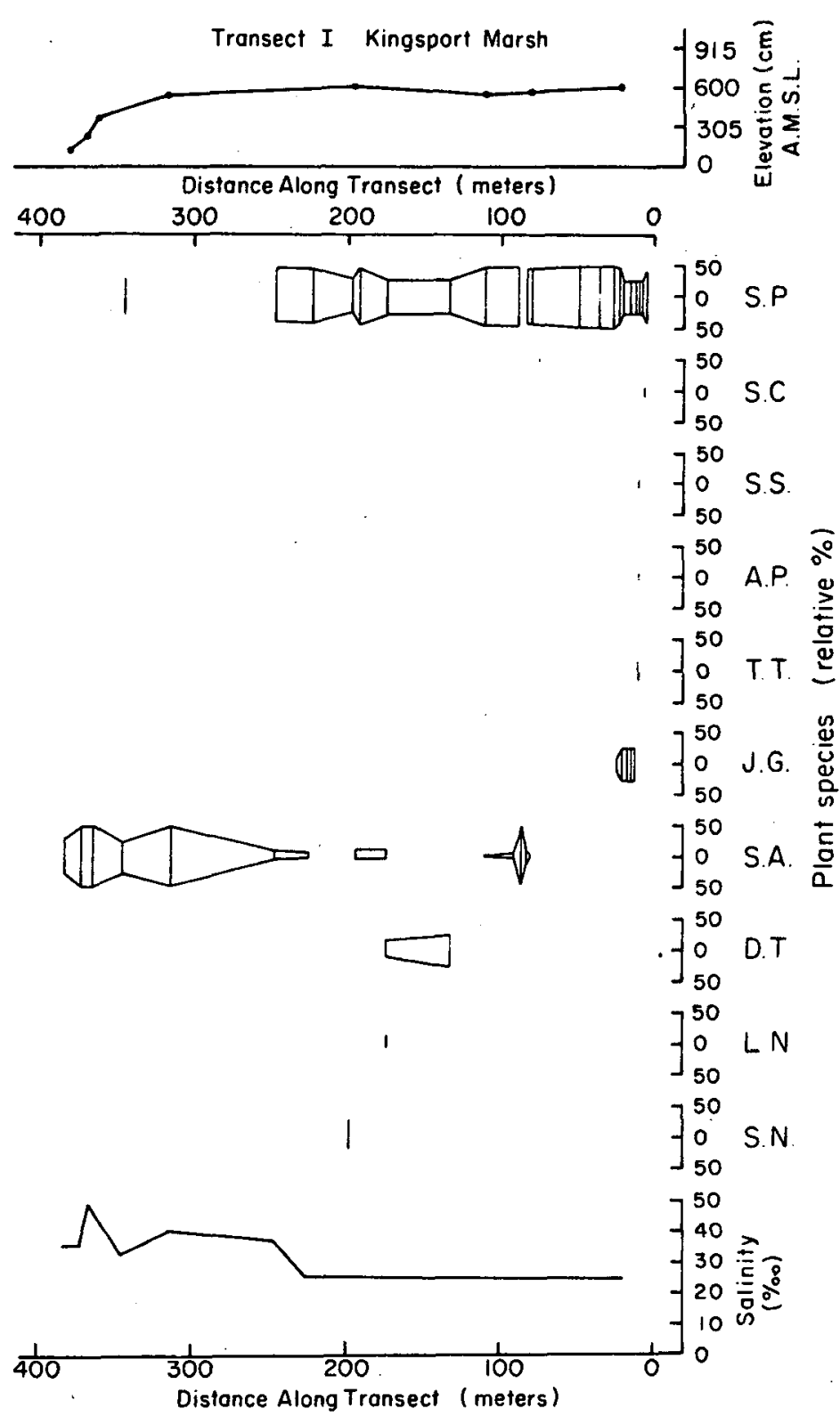

Fig. 2 - Vegetation occurrences along Transect I at Kingsport. Vertical bars are percentages at each station Dots on line representing transect are survey points. Not every station was surveyed so some averaging was done in between. There were no survey points above $6.00 \mathrm{~m}$ a.m.s.l. and plant zones were used to locate stations near and above HHW. HHW here is $7.75 \mathrm{~m}$ a.m.s.l. as determined from nearby tide gauges.

Legend for vegetation figures

A.P. - Atriple

D.T. - Distichis

J.G. - Juncus gerardii

L.N. - Limonium

P.O. - Plantago

S.C. - Spartina cynosuroides
S.N. - Salicornia

S.S. - Solidago sempervirens

S.A. - Spartina alterniflora

S.P. - Spartina patens

S.D. - Suaeda

T.T. - Terrestrials 
and floral content to those in other Atlantic marshes (Scott and Medioli 1980a, Figures 2 \& 3). Spartina alterniflora dominates the low marsh, with S. alterniflora and Spartina patens defining the mid-marsh, and Juncus gerardii and S. patens characterizing high marsh floral zones.

Salinities along Kingsport Transect I follow a relatively normal pattern (Figure 2 \& 3) for temperate marsh areas, with increasing salinity as elevation decreases (Scott and Medioli 1980a). However, Kingsport Transect II shows decreasing salinity with decreasing elevation; this trend may be the result of the low number of values obtained ( 3 out of 11 stations). The salinity throughout both transects is relatively high (Kingsport I, 31-38\%, Kingsport II, 25-48\%) as compared to those observed by Scott et al. (1981) in Prince Edward Island (Pisquid, 0-15\% Tryon 0-23\%, Wolfe Inlet $0-17 \%$ ) and those fluctuations recorded by Scott and Medioli (1980b) at Chezzetcook Inlet, N.S.

The marsh was dry and salinities high because evaporation at the time of collection was higher than precipitation or runoff, causing elevated salinities. Also, since there are higher tides and more sediment input (Harrison and Bloom 1977), the organic content of these marsh sediments is lower than other Maritime marshes. This means that drainage is better and fresh water is not retained in the sediments at low tide.

\section{Foraminiferal Results}

Each sample collected along the two Kingsport transects was examined for both living and total numbers of benthonic foraminifera (see Tables 1-3). Total populations were used to derive assemblage zones rather than living populations since the total population best illustrates the overall marine conditions by not over-emphasizing any seasonal variations that may occur (Scott and Medioli 1980b). At Kingsport, the irregularity of the living population along the transects makes

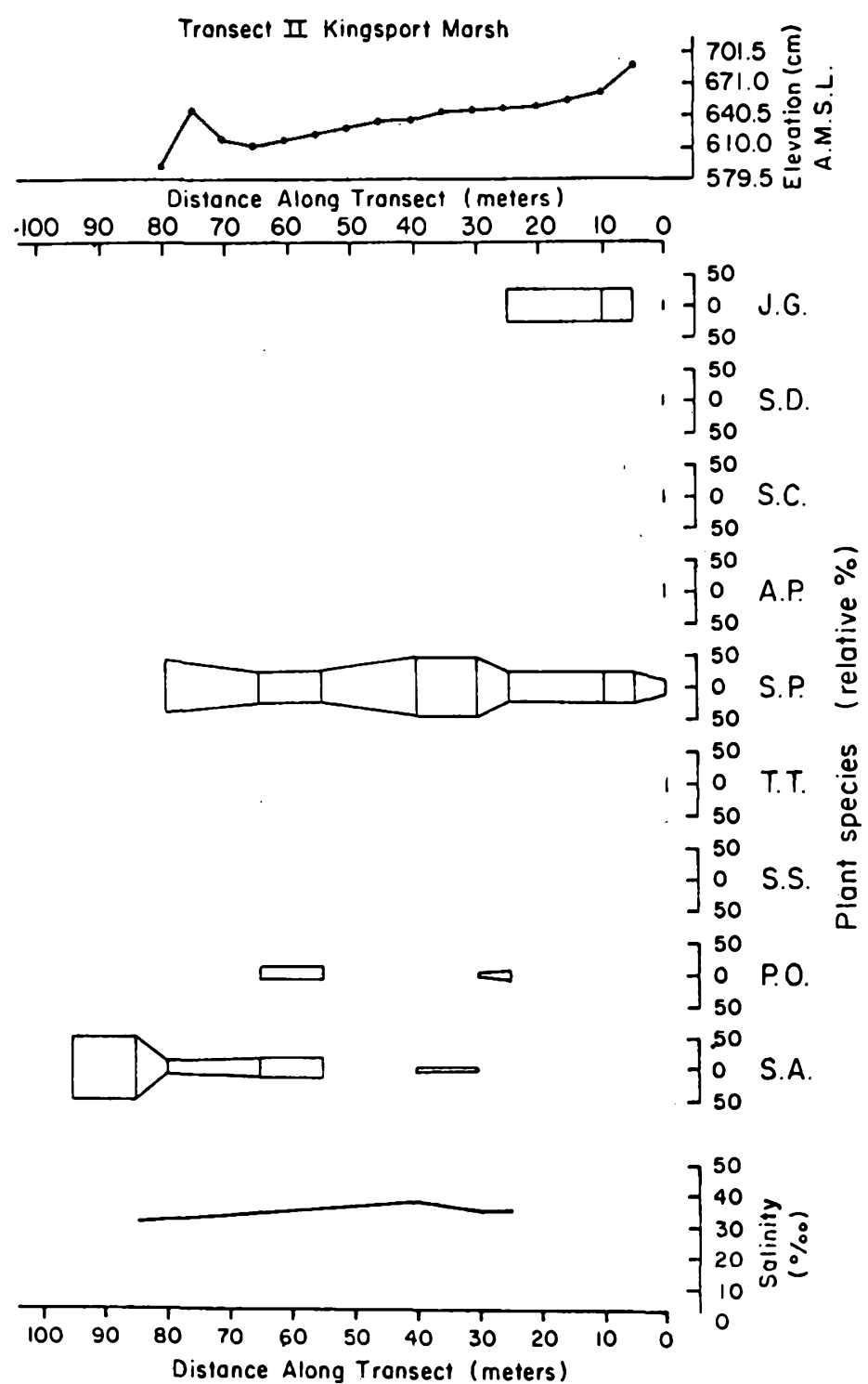

Fig. 3 - Vegetation occurrences along Transect II, Kingsport. Format same as Figure 2 and legend applied here. All stations were on survey points except station I which was above HHW and again located using plant zones.

their quantitative interpretation difficult. The $37(\times 2)$ surface samples contained a total of 17 species of foraminifera, with $70 \%$ of the species having living representatives. Living populations vary between 0 and $500 / 10$ $\mathrm{cm}^{3}$, while total populations vary from 0 to $1200 / 10 \mathrm{~cm}^{3}$.

In the two transects, using the marsh zone designations of Scott and Medioli (1980a), Zone I is defined by the abundance of Trochammina inflata, the presence of Tiphotrocha 


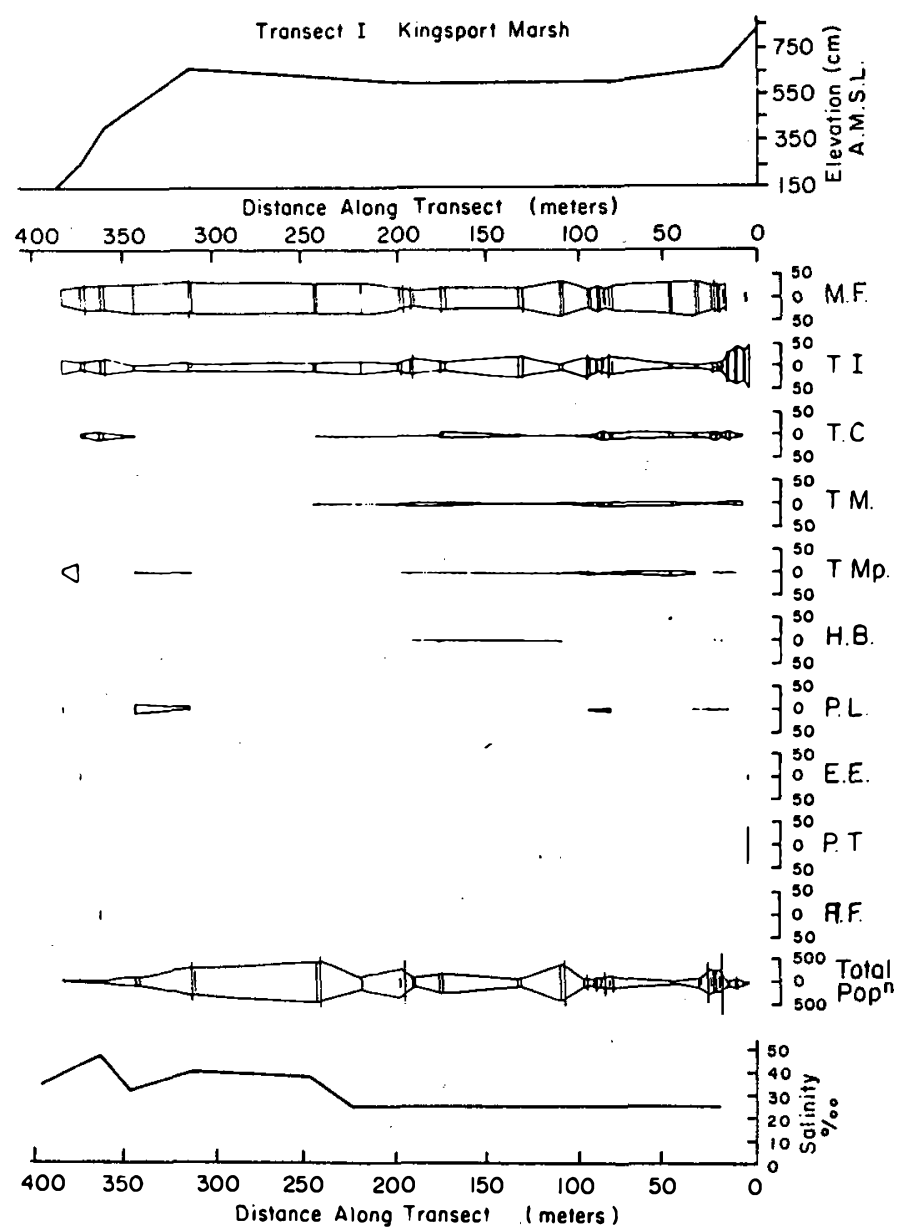

Fig. 4 - Foraminiferal occurrences in Transect I, Kingsport. Vertical lines are percentages with two values at each station. Stations are the same as plant stations. Station I (Table I) is the highest.

Legend for foraminiferal figures

$$
\begin{aligned}
& \text { A.F. - Ammobaculites dilatatus } \\
& \text { E.E. - Elphidium excavatum } \\
& \text { E.I. - Elphidium incertum } \\
& \text { H.B. - Haplophragmoides bonplandi } \\
& \text { H.O. - Haynesina orbiculare } \\
& \text { M.F. - Miliammina fusca } \\
& \text { P.T. - Planktonics } \\
& \text { P.L. - Pseudothurammina } \\
& \text { limnetis } \\
& \text { T.C. - Tiphotrocha } \\
& \text { comprimata } \\
& \text { T.I. - Trochammina inflata } \\
& \text { T.M. - Trochammina } \\
& \text { macrescens } \\
& \text { T.Mp. - T. macrescens F. } \\
& \text { polystoma }
\end{aligned}
$$

comprimata and limited occurrence of Trochammina macrescens forma polystoma. Zone II is well defined by the dominance of Miliammina fusca and $T$. inflata (Figs. 4,5). Zone I has a total vertical range of $0.75 \mathrm{~m}$ (6.75 $\mathrm{m}$ to $7.50 \mathrm{~m}$ a.m.s.l.), while Zone II has a total vertical range of $5.25 \mathrm{~m}(1.50 \mathrm{~m}$ to $6.75 \mathrm{~m})$.

The Zone I divisions possible in other Maritime marshes are not the same here but it does appear that locally Zone Ia is defined by greater than $90 \%$ T. inflata. Zone Ib shows increased $T$. comprimata together with T. inflata. Zone Ia has the vertical range of about +7.30 to $+7.50 \mathrm{~m}$ a.m.s.l. (samples were not sufficiently closely spaced to define it exactly) with Zone Ib having the range +6.75 to $+7.30 \mathrm{~m}$ a.m.s.l. Zone II can be differentiated into two subzones, IIa (6.0 to $6.75 \mathrm{~m}$ a.m.s.l.) and Zone IIb (1.5 $\mathrm{m}$ to 6.0 a.m.s.l.). Subzone Ila is delineated by the abundance, in almost equal numbers, of $T$. inflata and. $M$. fusca, as well as the absence of living Trochammina macrescens forma polystoma. Subzone IIb is defined on the basis of an increased percentage of M. fusca, the increasing percentage of Haynesina orbiculare, Ammobaculities dilatatus, and the occurrence of other calcareous estuarine species. The lower portion of subzone IIb (near the base of marsh vegetation) is distinguished by the rapid decrease of arenaceous species and total populations.

\section{Drill Hole Results}

Kingsport Marsh - The three drillholes at this location ranged in depth from 3.7 metres to 9.5 metres, and all contained an uninterrupted sequence of marsh deposits (Fig. 6). All drillholes at this location were similar in their foraminiferal assemblages, with $T$. inflata dominating (Fig. 7). Total populations decreased towards the bottom of the holes. Tiphotrocha comprimata and Trochammina macrescens were also present but in 


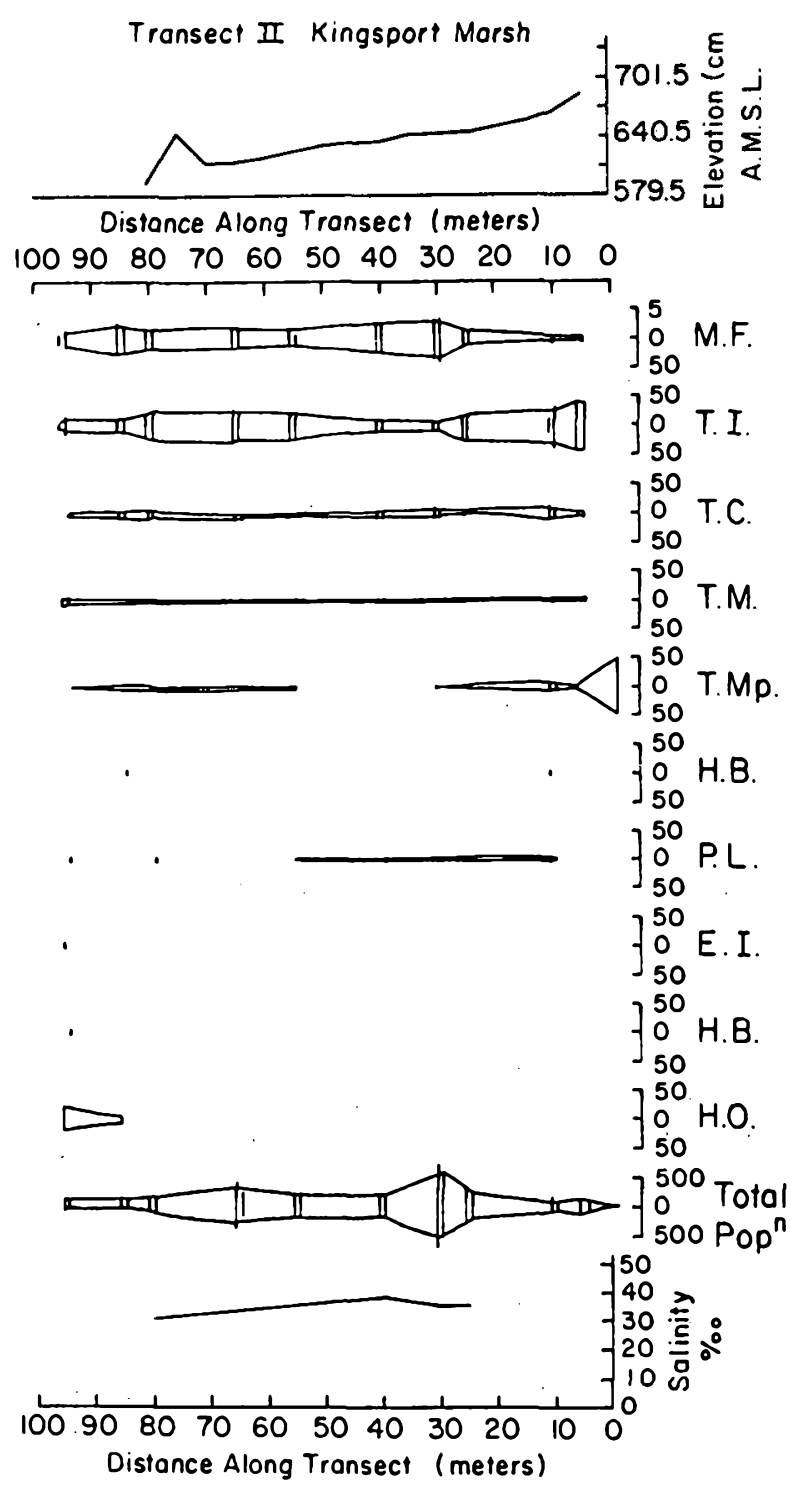

Fig. 5 - Foraminiferal occurrences along Transect II, Kingsport. Legend and format same as Figure 4. All stations same as plant stations.

small numbers. This is a Zone Ia assemblage (Bay of Fundy type) and the decrease in total populations near the base of each hole records the formation of HHW deposits over supra-tidal deposits as sea level rises.

Granville Ferry - Three holes were drilled at this site (Fig. 8), all exhibiting a continuous sequence of marsh sediments resting on glacial till. Total populations in these samples varied from 10 to 590 specimens per sample, with $T$. inflata dominating (Fig. 9). The numbers of $T_{\text {. inflata }}$ decrease with depth, indicating a pro- gression of marsh sediments through the upper marsh (Fig. 9). Trochammina macrescens is not prevalent in any of the holes, but T. comprimata is present in significant numbers. Unlike the Kingsport Marsh the foraminiferal assemblages vary from hole to hole. Relatively high percentages of Pseudothurammina limnetis and other species (T. comprimata, Haplophragmoides bonplandi) indicate Zone $\mathrm{Ib}$ at the base of each of these holes.

Mary's Point - Four holes were drilled at this location (Fig. 10), ranging in depth from 3.0 to 8.3 metres, all displaying unbroken sequences of marsh deposition. All four cores are similar in their foraminiferal assemblages (Fig. 11). T. macrescens is dominant in all holes, and its total population increases towards the basal sections, indicating a Zone la (Atlantic marsh type) elevation range at the base.

Ft. Beausejour - This marsh was drilled at four localities, with the depth of the holes ranging from 1.7 metres to 13 metres (Fig. 12). At the base of the holes, lower total numbers, together with the dominance of $T$. macrescens, indicate a Zone la fauna (Atlantic marsh type, Fig. 13). In drill hole I the basal sediment has a high percentage of Haynesina orbiculare (a calcareous form) as well as T. macrescens and is probably not a Zone Ia. Total numbers are so low that it is difficult to substantiate a particular zone, however, the presence of detrital wood combined with the low foraminiferal numbers in peat led us to place this as a HHW deposit.

$\mathrm{C}^{14}$ dating was used to date material from the base of the cores (Figs. 7, 9, 11, 13).

\section{DISCUSSION}

\section{Surface Floral Relationships}

Kingsport Marsh exhibits three well defined vertical plant zonations (Figs. 2,3). Scott and Medioli (1980a) illustrated the floral zonation of marshes to be similar throughout Nova Scotia, although some striking individual dif- 
TABLE 1

Percentage occurrences of Foraminifera along Transect 1 (stations 1-16) at Kingsport (Jadammina polystoma $=\mathrm{T}$. macrescens $\mathrm{F}$. polystoma in all tables). Stations $1-3$ are highest in elevation above HHW. Station 4 represents zone la, 5 is zone $\mathrm{Ib}$, 6 and 7 are zone lla and all others are in IIb.)

\begin{tabular}{|c|c|c|c|c|c|c|c|c|c|c|c|c|c|c|c|c|c|c|c|c|c|c|c|c|c|c|c|c|c|c|c|c|}
\hline STATION NUMBER & IA & IB & $2 A$ & $2 \mathrm{~B}$ & $3 \mathrm{~A}$ & 38 & $4 \mathrm{~A}$ & 48 & $5 A$ & $5 B$ & $6 A$ & $6 B$ & $7 A$ & $7 \mathrm{~B}$ & $8 \mathrm{~A}$ & $8 B$ & 9A & $9 \mathrm{~B}$ & $10 \mathrm{~A}$ & $10 \mathrm{~B}$ & IIA & 118 & $12 \mathrm{~A}$ & $12 B$ & $13 \mathrm{~A}$ & 13B & $14 \mathrm{~A}$ & 148 & 15A & 158 & $16 \mathrm{~A}$ & 168 \\
\hline NO. OF SPECIES & 0 & 0 & 2 & 1 & 4 & 3 & 2 & 4 & 3 & 4 & 7 & 5 & 6 & 7 & 5 & 5 & 5 & 5. & 5 & 5 & 6 & 5 & 6 & 5 & 5 & 6 & $\mathbf{s}$ & 6 & 5 & 5 & 6 & 5 \\
\hline TOTAL POPn $10 \mathrm{CM}^{3}$ & 0 & 0 & 32 & 4 & 67 & 69 & 189 & 322 & 54 & 52 & 368 & 1477 & 452 & 470 & 275 & 914 & 148 & 192 & 64 & 41 & 395 & 214 & 464 & 200 & 321 & 156 & 215 & 426 & 1027 & 810 & 112 & 313 \\
\hline TOTAL LIVING & 0 & 0 & 0 & 0 & 0 & 19 & 6 & 14 & 23 & 30 & 54 & 204 & 38 & 22 & 32 & 128 & 1 & 5 & 6 & II & 60 & 32 & 28 & 50 & 10 & 5 & 59 & 98 & 12 & 31 & 20 & 35 \\
\hline $\begin{array}{l}\text { Ammobaculities } \\
\text { dilatatus }\end{array}$ & $\stackrel{\mathrm{L}}{\mathrm{T}}$ & & & & & & & & & & & & & & & & & & & & & & & & & & & & & & & \\
\hline $\begin{array}{l}\text { Cibicides } \\
\text { lobatulus }\end{array}$ & $\mathrm{T}$ & & 13 & & & & & . & & & & & & & & & & & & & & & & & & & & & & & & \\
\hline $\begin{array}{l}\begin{array}{l}\text { Elphidium } \\
\text { bartletti }\end{array} \\
\end{array}$ & $\begin{array}{l}\mathrm{L} \\
\mathrm{T}\end{array}$ & & & & & & & & & & & & & & & & & & & & & & & & & & & & & & & \\
\hline $\bar{E}$ excavatūiun & $\frac{\mathrm{L}}{\mathrm{T}}$ & & & & & & & & . & & & & & & & & & & & & & & & & & & & & & & & \\
\hline E. incertum & $T$ & & & & & & & & & & & & & & & & & & & & & & & & & & & & & & & \\
\hline 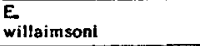 & $\mathbf{L}$ & & & & & & & & & & & & & & & & & & & & & & & & & & & & & & & \\
\hline $\begin{array}{l}\text { Haplophragmoides } \\
\text { bonplandf }\end{array}$ & $\mathbf{T}$ & & & & & & & & & & 2 & & & .42 & & & & & 3 & 7 & & .9 & & & & & & & & & 2 & \\
\hline $\begin{array}{l}\text { Haynesina } \\
\text { orbiculare } \\
\end{array}$ & $\begin{array}{l}T \\
T \\
\end{array}$ & & & & & & & 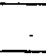 & & & & & & & & & & & . & & & & & & & & & & & & & \\
\hline $\begin{array}{l}\text { Hemisphaerammina } \\
\text { bradyi }\end{array}$ & $\begin{array}{l}\mathrm{L} \\
\mathrm{T}\end{array}$ & & & & & & & & & & & & & & & & & & & & & & & & & & & & & & & \\
\hline $\begin{array}{l}\text { Jadammina } \\
\text { polystoma }\end{array}$ & $\frac{L}{T}$ & & & & & & & 1 & & & $\mathbf{I}$ & & $\begin{array}{l}5 \\
2\end{array}$ & $\begin{array}{c}8 \\
.20\end{array}$ & & & & 2 & 5 & & 2 & & .4 & I & .9 & $i$ & $\begin{array}{r}12 \\
8\end{array}$ & 2 & 2 & & $\begin{array}{r}25 \\
5\end{array}$ & \\
\hline $\begin{array}{l}\text { Miliammina } \\
\text { fusce }\end{array}$ & L & & & & 24 & $\begin{array}{l}42 \\
26 \\
\end{array}$ & & & & & $\begin{array}{l}41 \\
46 \\
\end{array}$ & 69 & 55 & $\begin{array}{l}47 \\
71 \\
\end{array}$ & 59 & 82 & $\begin{array}{c}100 \\
77 \\
\end{array}$ & 82 & $\begin{array}{l}67 \\
72 \\
\end{array}$ & $\begin{array}{l}73 \\
71 \\
\end{array}$ & $\begin{array}{l}23 \\
53 \\
\end{array}$ & 34 & $\begin{array}{l}50 \\
38 \\
\end{array}$ & $\begin{array}{l}72 \\
58 \\
\end{array}$ & 63 & 65 & $\begin{array}{r}5 \\
33 \\
\end{array}$ & $\begin{array}{l}35 \\
50 \\
\end{array}$ & $\begin{array}{l}25 \\
84 \\
\end{array}$ & 80 & 25 & 38 \\
\hline Plankeonics & 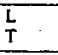 & & 88 & & & & & & & & & & & . & & & & & & & & & & & & & & & & & & \\
\hline $\begin{array}{l}\text { Pseudothurammina } \\
\text { Ifmnetis }\end{array}$ & L & & & & & & & & & 4 & 2 & 1 & 3 & 4 & 1 & .43 & 7 & & & & 1 & & .4 & & & 7 & & .9 & & 4 & & 3 \\
\hline $\begin{array}{l}\text { Tiphotrocha } \\
\text { comprimata }\end{array}$ & $\mathrm{T}$ & & & & $B$ & & & 3 & $\begin{array}{c}8 \\
17 \\
\end{array}$ & $\begin{array}{l}10 \\
25\end{array}$ & $\begin{array}{l}15 \\
14\end{array}$ & $\begin{array}{l}32 \\
12 \\
\end{array}$ & $\begin{array}{l}74 \\
26\end{array}$ & $\begin{array}{l}27 \\
12\end{array}$ & $\begin{array}{l}44 \\
19 \\
\end{array}$ & $\begin{array}{l}41 \\
8\end{array}$ & 9 & $\begin{array}{r}80 \\
8\end{array}$ & $\begin{array}{l}33 \\
16 \\
\end{array}$ & 5 & $\begin{array}{l}37 \\
17\end{array}$ & $\begin{array}{l}6 \\
7\end{array}$ & $\begin{array}{l}14 \\
22\end{array}$ & $\begin{array}{r}8 \\
17\end{array}$ & $\begin{array}{r}40 \\
6\end{array}$ & $\begin{array}{r}40 \\
7\end{array}$ & $\begin{array}{r}8 \\
10\end{array}$ & $\begin{array}{l}4 \\
6\end{array}$ & 2 & $\begin{array}{c}16 \\
1\end{array}$ & 10 & $\begin{array}{r}40 \\
4\end{array}$ \\
\hline $\begin{array}{l}\text { Trochammina } \\
\text { inflata }\end{array}$ & L & & & 100 & & $\begin{array}{l}32 \\
64 \\
\end{array}$ & $\begin{array}{l}100 \\
93 \\
\end{array}$ & 90 & $\begin{array}{l}57 \\
78\end{array}$ & $\begin{array}{l}57 \\
62 \\
\end{array}$ & $\begin{array}{l}11 \\
30\end{array}$ & $\begin{array}{l}28 \\
16 \\
\end{array}$ & 12 & 10 & $\begin{array}{l}25 \\
20\end{array}$ & 8 & 3 & $\begin{array}{r}20 \\
4\end{array}$ & 5 & 10 & $\begin{array}{l}17 \\
25 \\
\end{array}$ & $\begin{array}{l}44 \\
56\end{array}$ & $\begin{array}{r}7 \\
39 \\
\end{array}$ & $\begin{array}{r}8 \\
22 \\
\end{array}$ & $\begin{array}{l}40 \\
29 \\
\end{array}$ & $\begin{array}{l}20 \\
16\end{array}$ & $\begin{array}{l}30 \\
45\end{array}$ & $\begin{array}{l}22 \\
63 \\
\end{array}$ & $\begin{array}{l}50 \\
14\end{array}$ & $\begin{array}{l}65 \\
14 \\
\end{array}$ & $\begin{array}{l}45 \\
55\end{array}$ & 53 \\
\hline $\begin{array}{l}\text { Trochammina } \\
\text { marcrescens }\end{array}$ & $\stackrel{i}{T}$ & & & & & $\begin{array}{c}26 \\
10 \\
\end{array}$ & 7 & $\begin{array}{r}100 \\
7\end{array}$ & $\begin{array}{r}39 \\
6 \\
\end{array}$ & $\begin{array}{l}33 \\
14\end{array}$ & $\begin{array}{r}33 \\
4\end{array}$ & $\begin{array}{r}36 \\
2\end{array}$ & $\begin{array}{r}21 \\
3\end{array}$ & $\begin{array}{r}18 \\
2 \\
\end{array}$ & $\begin{array}{r}25 \\
4\end{array}$ & $\begin{array}{c}7 \\
.76 \\
\end{array}$ & .67 & 3 & & $\begin{array}{r}27 \\
7 \\
\end{array}$ & $\begin{array}{r}23 \\
3\end{array}$ & $\begin{array}{r}50 \\
4\end{array}$ & $\begin{array}{l}29 \\
.4\end{array}$ & $\begin{array}{r}12 \\
3\end{array}$ & $\begin{array}{l}20 \\
.9\end{array}$ & $\begin{array}{r}40 \\
4\end{array}$ & $\begin{array}{r}44 \\
5\end{array}$ & $\begin{array}{r}37 \\
2\end{array}$ & $\begin{array}{l}25 \\
.2\end{array}$ & $\begin{array}{l}19 \\
.5\end{array}$ & $\begin{array}{r}30 \\
4\end{array}$ & $\begin{array}{c}60 \\
3\end{array}$ \\
\hline
\end{tabular}

ferences are observed. The plant species that define the zones at Kingsport are no exception. The upper zone of the Kingsport Marsh is defined by the dominance of elevation sensitive Juncus gerardii and Spartina patens while Scott and Medioli (1980a) record the upper of zone of Chezzetcook, N.S. to be defined by Spartina cynosuroides or Cyperaceae; at Chebogue, N.S., they observed various combinations of J. gerardii, Solidago sempervirens and Cyperaceae and at Newport Landing (also in the Bay of Fundy) J. gerardii and S. sempervirens dominated. The Prince Edward Island marshes, as reported by Scott et al. (1981), contained high marsh components different than those found anywhere in the Maritimes. Due to the interchangeable nature of the high marsh flora in Eastern Canada, the possibility of making paleo-sea level determinations based on ancient marsh plant assemblages is difficult.

In the Bay of Fundy some tidal ranges are greater than 15 metres, hence the marsh flora of Kingsport no longer extend down to mean sea level, as do marshes with normal tidal ranges (Scott and Medioli 1980a). This high tidal range may be one reason for the elevated salinities at Kingsport (Figs。 3,4), and the absence of the Cyperaceae and $\mathbf{S}$. cynosuroides in the upper marsh.

Scott and Medioli (1980a) had suggested that the maximum vertical range of a marsh could be no more than $3.5 \mathrm{~m}$ from work at Newport Landing but the work here was shown that to be too low an estimate since we see total marsh vertical ranges of up to $6.0 \mathrm{~m}$ at Kingsport. The variation between Kingsport and Newport Landing, just across the bay, may be the result of the more protected environment at Kingsport.

\section{Foraminiferal Relationships}

The foraminiferal assemblages along both Kingsport transects were similar 


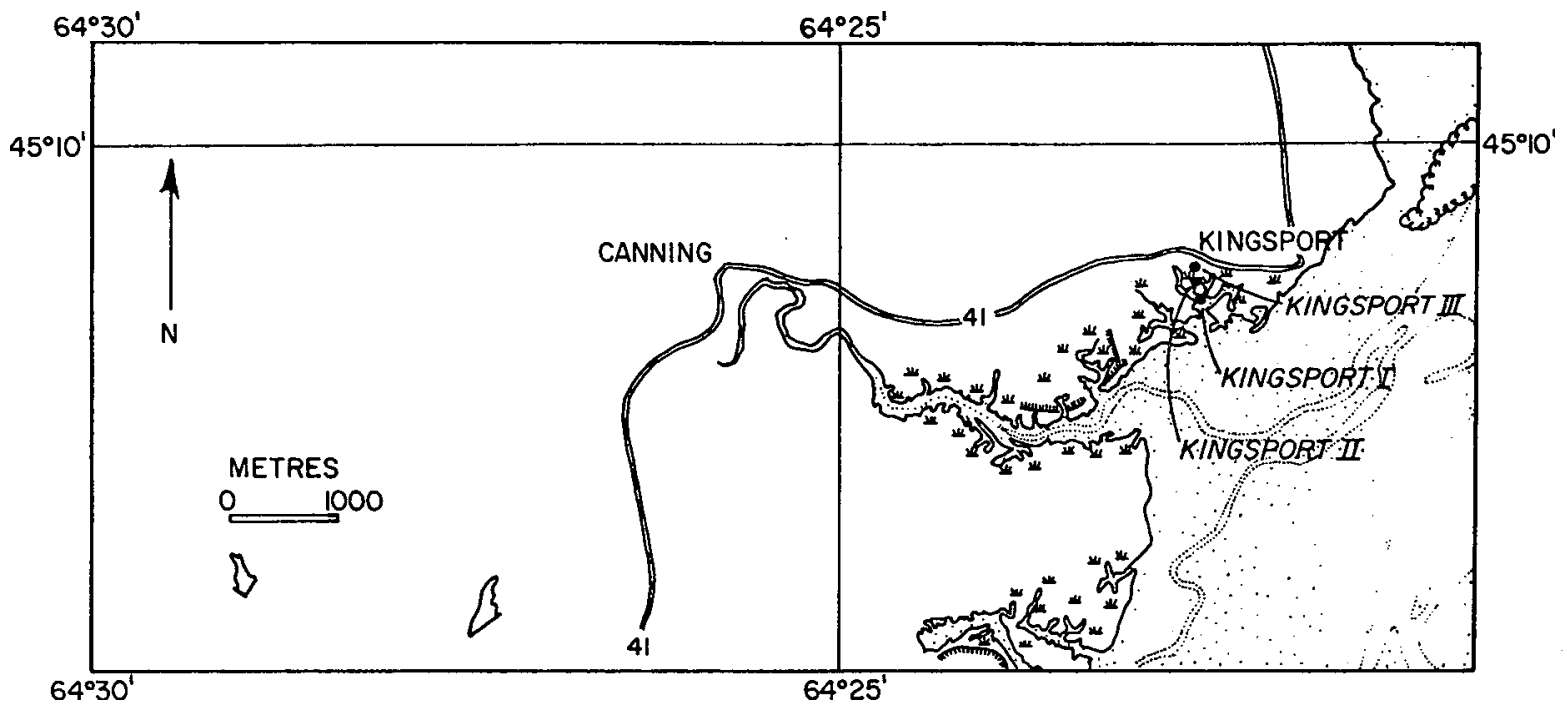

Fig. 6 - Detailed location map of Kingsport drill holes. 41 is Hwy 41 and marsh is indicated by hatch marks. Dotted areas are intertidal mudflats. Figures 6, 8, and 10 are all redrafted from standard topo sheets.

considering the differences in horizontal distances, elevation and salinity.

At Kingsport, the species that defines the high marsh Zone I is Trochammina inflata, in contrast with Trochammina macrescens found by Scott and Medioli (1978, 1980a) and Scott et al. (1981) in other Atlantic marshes. The dominance of $\mathbf{T}$. inflata in this zone, together with rare occurrences of $T$. macrescens, is indicative of a highly saline environment, as observed by Scott and Medioli (1980a) in the Summerville marsh, Nova Scotia. Here $T$. inflata replaces $T$. macrescens as the Zone Ia indicator but $T$. comprimata still characterizes Zone Ib (together with $T$. inflata). The absolute range of Zone Ia is increased so that its accuracy as a paleo-sealevel indicator is $\pm 20 \mathrm{~cm}$ instead of the $\pm 5 \mathrm{~cm}$ possible in Atlantic marshes. The dominance of $T$. inflata here makes the high marsh assemblage more comparable to that observed in other high salinity marshes worldwide (e.g. S. California, Scott 1976; Italy, Petrucci et al. 1983). The lower Zone II at Kingsport exhibits sharp decreases in total populations, with living percentages remaining relatively constant. This represents a dilution of total foraminiferal populations as a result of sediment accumulation at the base of the marsh (Scott and Medioli 1980a; Harrison and Bloom 1977).

Absolute vertical ranges of the zones, since they are related to tidal range, are much higher here than in marshes with lower tidal ranges. However, as observed by Scott and

Medioli (1980a) in nearby Newport Landing Marsh, the high marsh Zone I at Kingsport has absolute vertical range of $75 \mathrm{~cm}$. This is about twice the vertical width of comparable zones on the Atlantic coast (Scott and Medioli 1980a) but these zones still provide a sea level with an accuracy of $\pm 20 \mathrm{~cm}$ if the Trochammina inflata dominant Zone Ia is found. The low marsh zones, on the other hand, appear to absorb most of the tidal increase and are of little use as sealevel indicators.

Sea Level Changes - All cores taken from the four sampling sites on the Bay of Fundy (Fig. l) contained continuous sequences of marsh deposits, representing a continuous sea-level rise over the period of marsh deposition. Carbon-14 dating indicates this accumulation has occurred for the past $3525-4400$ years.

The examination of the foraminiferal assemblages classified the basal 


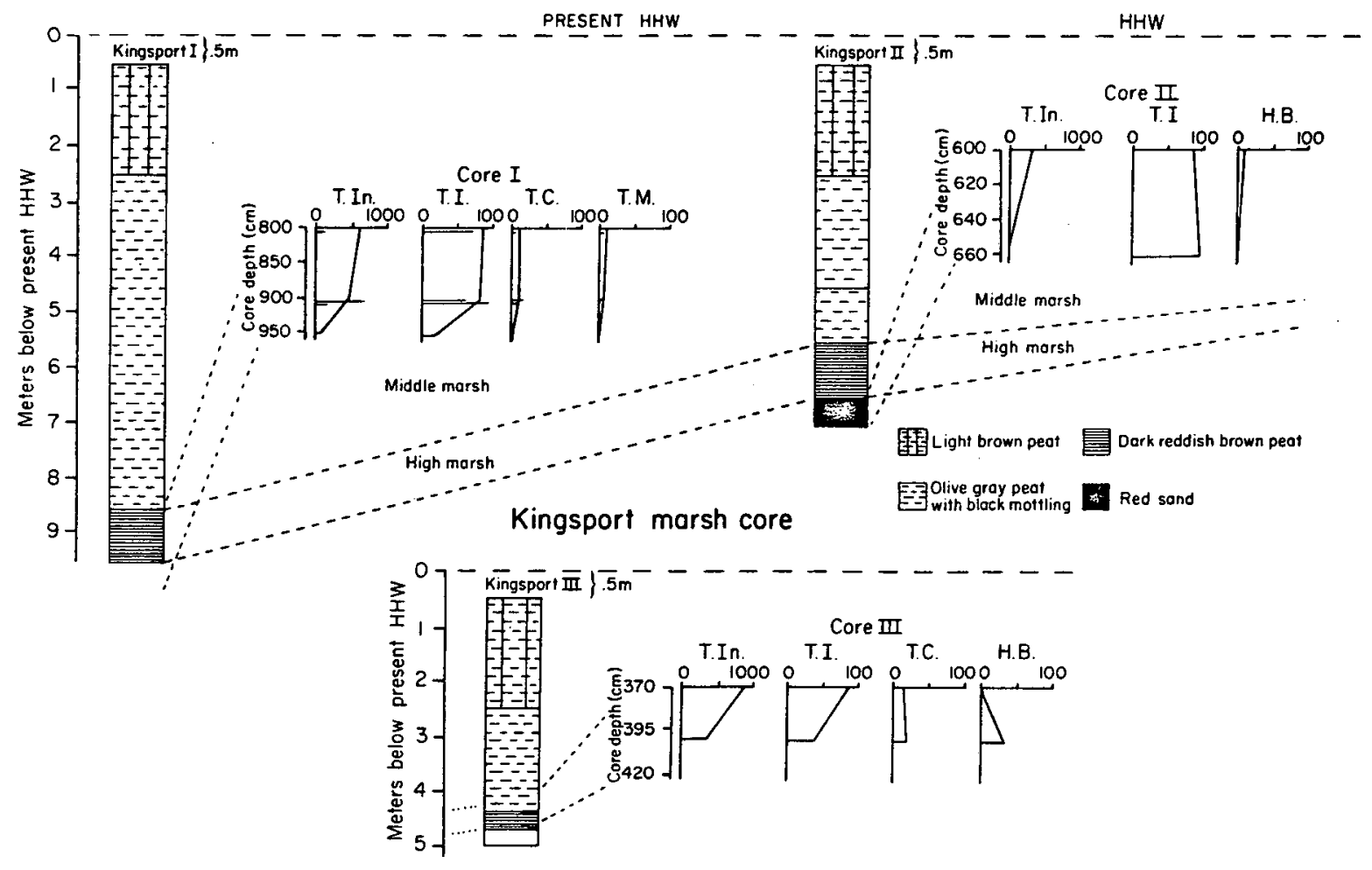

Fig. 7 - Lithologies and foraminiferal occurrences in the Kingsport marsh drill holes. Legend for foraminifera same as Figure 4, except that T.In. = total population.

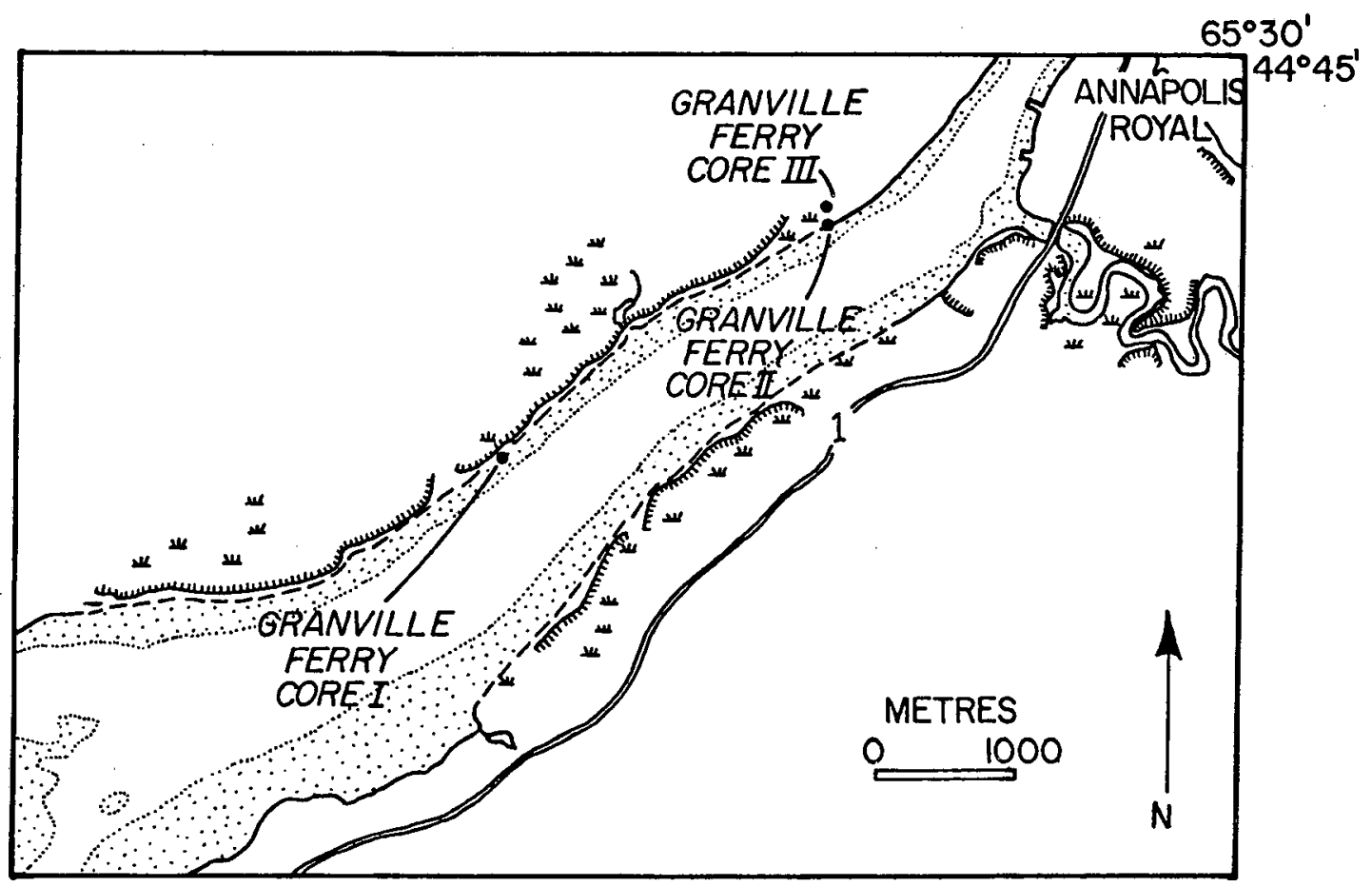

Fig. 8 - Detailed location map of Granville Ferry drill holes. Symbols same as Figure 6 except that dykes are indicated here by lines. 
TABLE 2

Percentage occurrences of Foraminifera along Transect I (stations 17-26) at Kingsport (All stations are in zone IIb.)

\begin{tabular}{|c|c|c|c|c|c|c|c|c|c|c|c|c|c|c|c|c|c|c|c|c|c|}
\hline STATION- NUMBER & & $17 \mathrm{~A}$ & $17 \mathrm{~B}$ & $18 \mathrm{~A}$ & $18 B$ & $19 \mathrm{~A}$ & 198 & $20 \mathrm{~A}$ & 208 & $21 \mathrm{~A}$ & 218 & $22 \mathrm{~A}$ & 228 & $23 \mathrm{~A}$ & 238 & $24 A$ & 248 & $25 \mathrm{~A}$ & $25 B$ & $26 \mathrm{~A}$ & 268 \\
\hline NO. OF SPECIES & & 7 & 5 & 7 & 5 & 6 & 5 & 4 & 0 & 6 & 7 & 5 & 5 & 5 & 0 & 3 & 4 & 4 & 4 & 4 & $\underline{0}$ \\
\hline TOTAL POP $10 \mathrm{CM}^{3}$ & & 439 & 394 & 222 & 197 & 1006 & 280 & 298 & $n$ & 1173 & 915 & 494 & 889 & 201 & 0 & 16 & 27 & 32 & 44 & 20 & 0 \\
\hline TOTAL LIVING & & 30 & 10 & 20 & 56 & 33 & 16 & 94 & 0 & 120 & 100 & 42 & 36 & $\underline{0}$ & 0 & 2. & 1 & 7 & 0 & 0 & $\underline{0}$ \\
\hline $\begin{array}{l}\text { Amnobaculities } \\
\text { dilatatus }\end{array}$ & $\underline{L}$ & .5 & & & & & & & & & & .8 & & & & 20 & & & & & \\
\hline $\begin{array}{l}\text { Anmotium } \\
\text { salsum }\end{array}$ & & & & & & : & & & & & & & & .4 & & 20 & & . & & & \\
\hline $\begin{array}{l}\text { Cibicides } \\
\text { lobatulus }\end{array}$ & $\frac{L}{T}$ & & & & & & & & & & & & & & & & & & & & \\
\hline $\begin{array}{l}\text { Elphidium } \\
\text { bartletti }\end{array}$ & L & & & & & & & & & & & & & & & & & & & & \\
\hline E. excavatum & $\mathrm{L}$ & & & & & & & & & & & & & & & & & $\begin{array}{r}100 \\
20 \\
\end{array}$ & 16 & & \\
\hline E. incertum & $\stackrel{L}{\mathrm{~L}}$ & & & & & & & & & & & & & & & & & & & & \\
\hline $\begin{array}{l}\text { Elphidium } \\
\text { williamsoni }\end{array}$ & $\stackrel{L}{T}$ & & & & & & & & & & & & & & & & & & & & \\
\hline $\begin{array}{l}\text { Haplophragmoides } \\
\text { bonplandi }\end{array}$ & $\stackrel{L}{T}$ & .4 & & .9 & & & & & & & .8 & & & & & & & & & & . \\
\hline $\begin{array}{l}\text { Haynesina } \\
\text { orbiculare }\end{array}$ & $\mathrm{L}$ & & & & & : & & & & & & & & & & & & & & & \\
\hline $\begin{array}{l}\text { Hemi sphaeram- } \\
\text { mina bradyi }\end{array}$ & L & & & & & & & & & & & & & & & & & & & & \\
\hline $\begin{array}{l}\text { Ja dammina } \\
\text { Dolystoma }\end{array}$ & $\underline{\mathrm{L}}$ & 1 & 2 & .9 & .5 & .2 & 4 & & & .6 & .6 & 2 & .7 & 6 & & & & 2 & 15 & & \\
\hline $\begin{array}{l}\text { Miliammina } \\
\text { fusca }\end{array}$ & L & 49 & $\begin{array}{l}20 \\
61 \\
\end{array}$ & $\begin{array}{l}40 \\
52 \\
\end{array}$ & 26 & 64 & $\begin{array}{l}25 \\
58 \\
\end{array}$ & $\begin{array}{l}46 \\
68 \\
\end{array}$ & & $\begin{array}{l}48 \\
75 \\
\end{array}$ & $\begin{array}{l}64 \\
75 \\
\end{array}$ & $\begin{array}{r}27 \\
67 \\
\end{array}$ & $\begin{array}{l}56 \\
88 \\
\end{array}$ & 61 & & 6 & 56 & 60 & 39 & 40 & \\
\hline Planktonics & L & & & & & & & & & & & & & & & & & & & & \\
\hline $\begin{array}{l}\text { Pseudothuram- } \\
\text { mina limnet is }\end{array}$ & L & & & 3 & & 1 & & & & 2 & 1 & 8 & 4 & 23 & & & & & & 20 & \\
\hline $\begin{array}{l}\text { Tiphotrocha } \\
\text { comprimata }\end{array}$ & $\mathrm{L}$ & $\begin{array}{r}53 \\
9 \\
\end{array}$ & $\begin{array}{l}20 \\
11 \\
\end{array}$ & & 1 & $\begin{array}{r}52 \\
3 \\
\end{array}$ & $\begin{array}{r}13 \\
4 \\
\end{array}$ & 1 & & $\begin{array}{r}20 \\
2 \\
\end{array}$ & 1 & & & .49 & & 19 & 4 & 8 & 11 & & \\
\hline $\begin{array}{l}\text { Trochammina } \\
\text { inflata }\end{array}$ & $\mathbf{L}$ & $\begin{array}{r}40 \\
36 \\
\end{array}$ & 20 & $\begin{array}{l}50 \\
39 \\
\end{array}$ & $\begin{array}{l}41 \\
68 \\
\end{array}$ & $\begin{array}{l}36 \\
20 \\
\end{array}$ & $\begin{array}{l}62 \\
34 \\
\end{array}$ & $\begin{array}{l}35 \\
31 \\
\end{array}$ & & $21^{x}$ & $\begin{array}{l}30 \\
21 \\
\end{array}$ & $\begin{array}{l}24 \\
22 \\
\end{array}$ & $\begin{array}{l}11 \\
11 \\
\end{array}$ & 10 & & 36 & $\begin{array}{r}100 \\
41 \\
\end{array}$ & 13 & 32 & 25 & \\
\hline $\begin{array}{l}\text { Trochammina } \\
\text { macrescens }\end{array}$ & $\begin{array}{l}1 \\
\end{array}$ & $\begin{array}{l}7 \\
3 \\
\end{array}$ & $\begin{array}{r}60 \\
7 \\
\end{array}$ & $\begin{array}{r}10 \\
5 \\
\end{array}$ & $\begin{array}{r}59 \\
5\end{array}$ & 11 & 1 & $\begin{array}{l}18 \\
.3 \\
\end{array}$ & & $\begin{array}{c}33 \\
.5\end{array}$ & 6 & $\begin{array}{c}49 \\
.2\end{array}$ & $\begin{array}{l}33 \\
11 \\
\end{array}$ & & & & & & & 2 & \\
\hline
\end{tabular}

core section as to their paleo-marsh zonation and hence their paleo-sealevel position. Although all cores contained different assemblages, either T. macrescens or T. inflata were dominant at the base. This corresponds relatively well to the data collected by Scott et al. (1981) at Orwell, Pisquid and Tyron marshes on Prince Edward Island, except these holes exhibited only dominant $T$. macrescens as basal assemblages. The bases of the holes at Kingsport and Granville Ferry are defined by a dominance of $T$. inflata which indicates the same Zone Ia as observed in the surface transects at Kingsport, producing an accuracy for these levels as a sea level indicators to $\pm 20 \mathrm{~cm}$. At both Ft. Beausejour and Mary's Point, a Zone Ia, similar to that observed on the Atlantic caost, was found and provides a precise level of $\pm 5 \mathrm{~cm}$.

Correction of Sea-level Data for Ti- dal Amplification - The Bay of Fundy displays the phenomenon of tidal amplification, caused by changes in water depth over Georges Bank and changes in the Bay of Fundy basin configuration (Scott and Greenberg 1983). At the point where ocean tides contact the edge of the continental shelf, the tides have a range of one metre. This one metre range is amplified through the system with the largest amplification occurring in the upper Bay of Fundy and ranging from $6 x$ in the central Bay of Fundy, 10x in Chignecto Bay and $12 \mathrm{x}$ in the Minas Basin at the head of the Bay of Fundy. Thus in order to determine the actual effects of relative sealevel rise using HHW indicators, one must be able to subtract the amount of tidal amplification. Scott and Greenberg (1983) have made these determinations (Table 4) possible by supplying a separate curve for tidal 


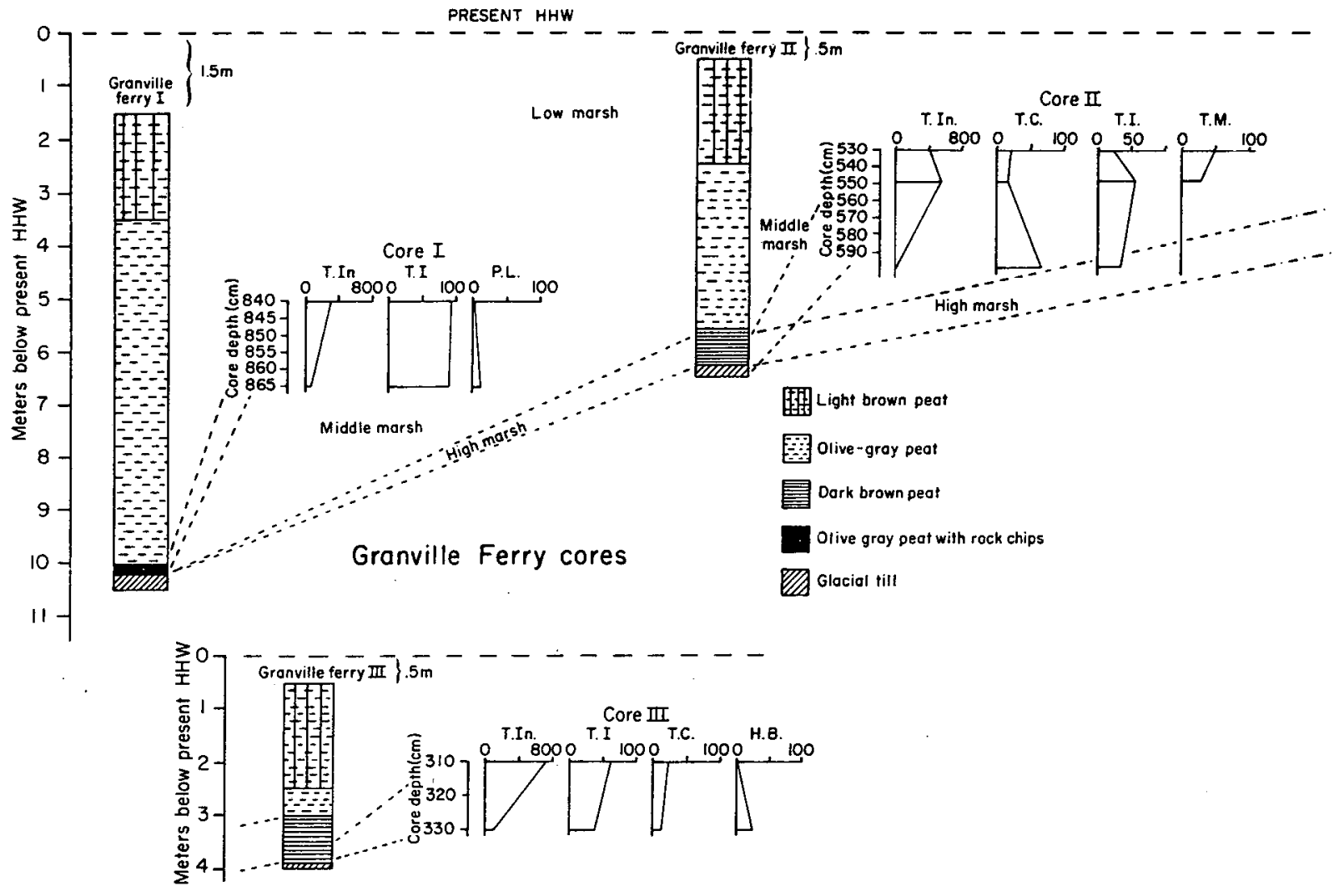

Fig. 9 - Lithologies and foraminiferal occurrences in the Granville Ferry drill holes. Legend is the same as Figure 4.

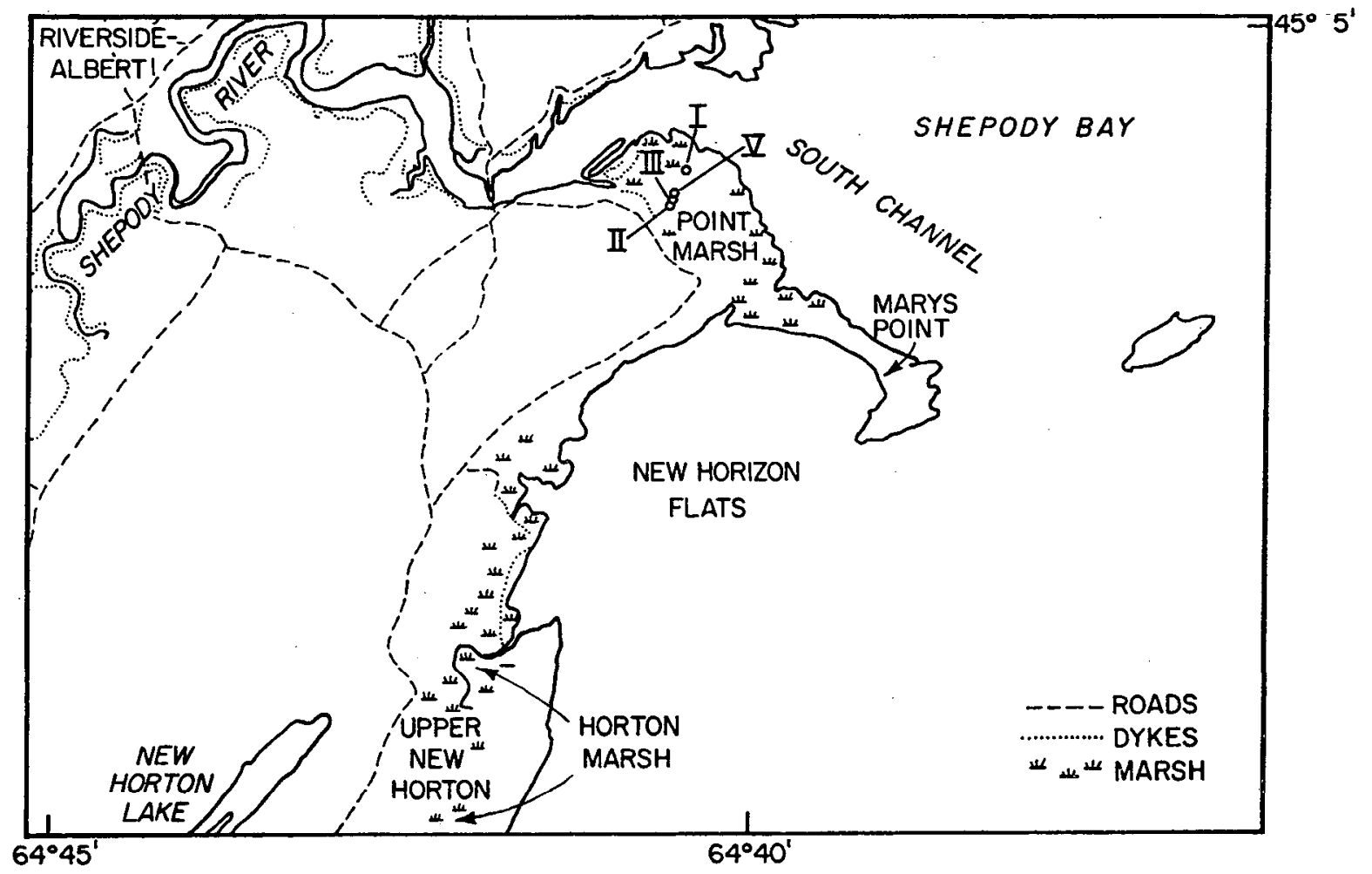

Fig. 10 - Detailed location map of Mary's Point drill holes. 

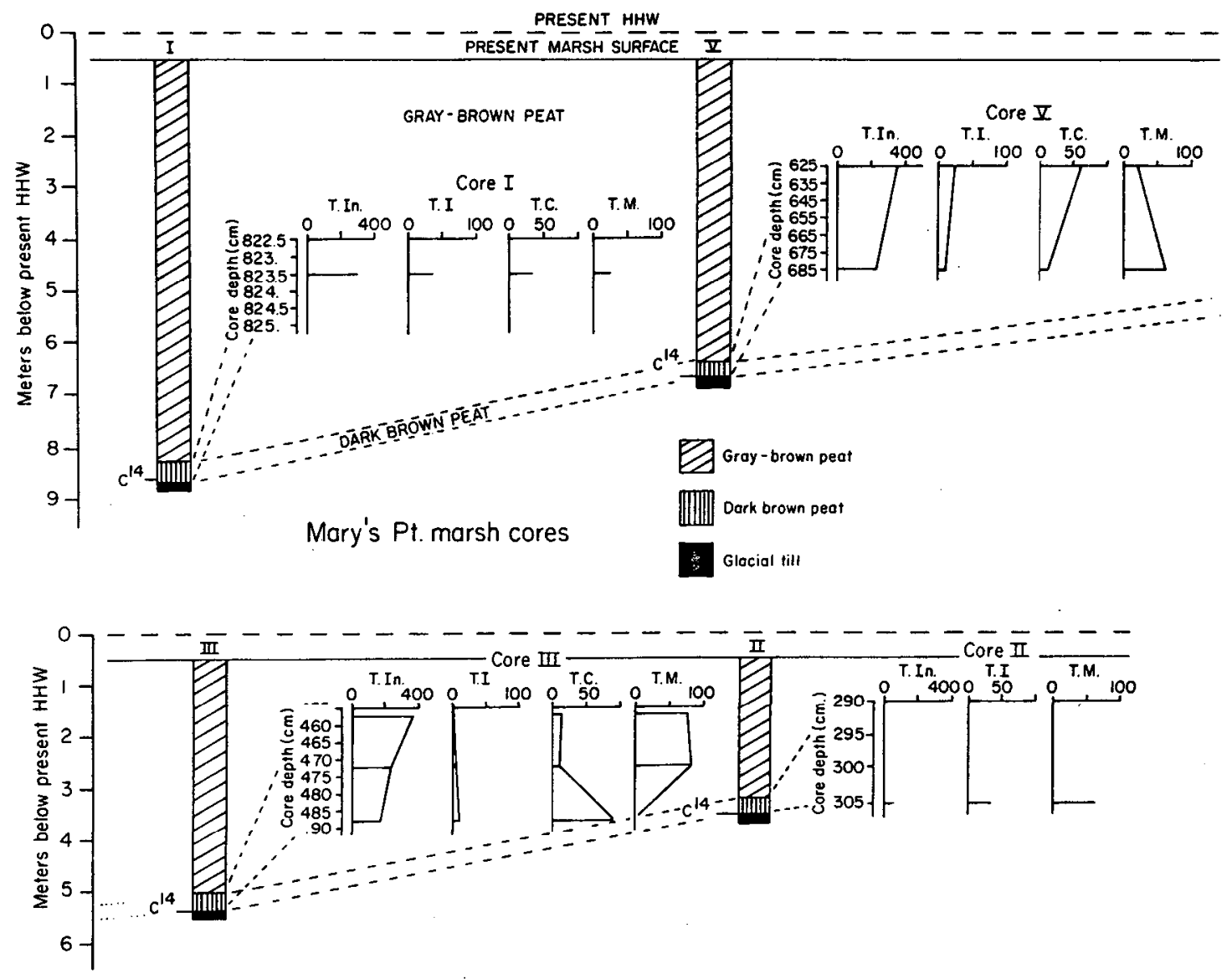

Fig. Il - Lithologies and foraminiferal occurrences in Mary's Point drill holes. Legend is the same as Figure 4.

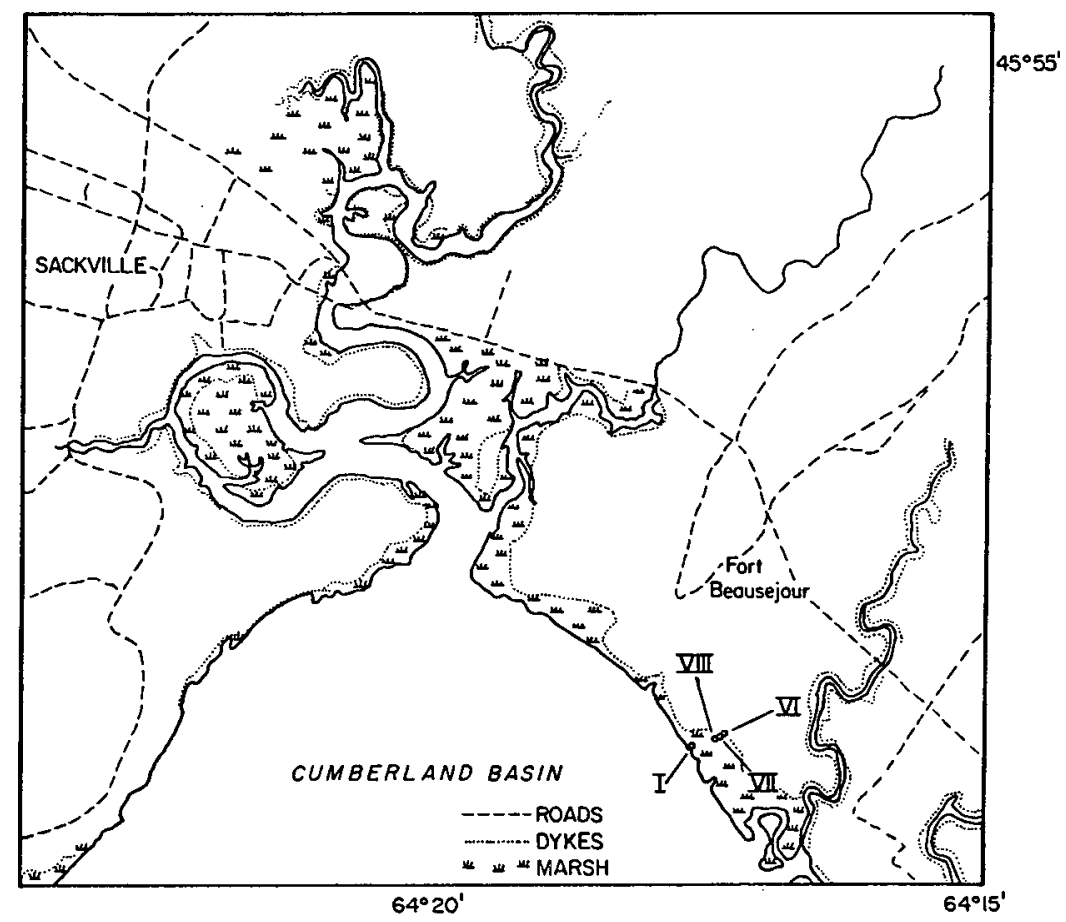

Fig. 12 - Detailed location map of Ft. Beausejour drill holes. 


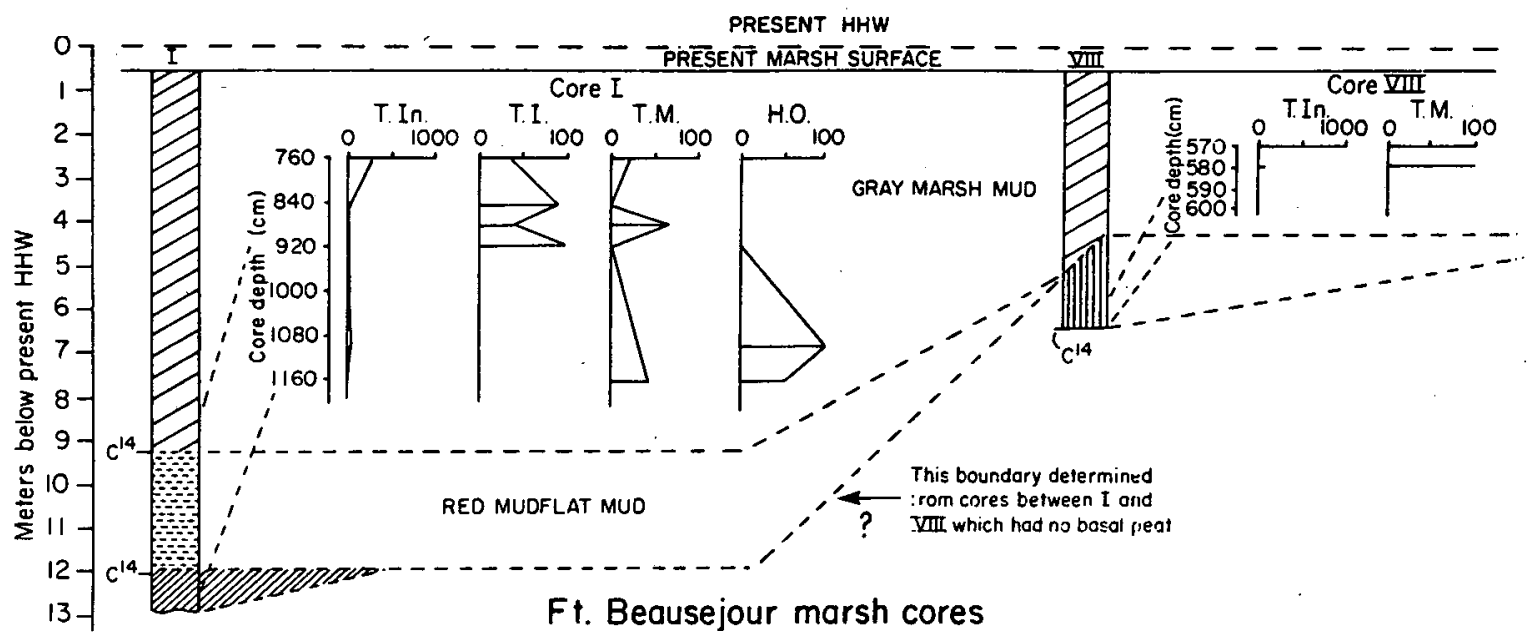

Ft. Beausejour marsh cores

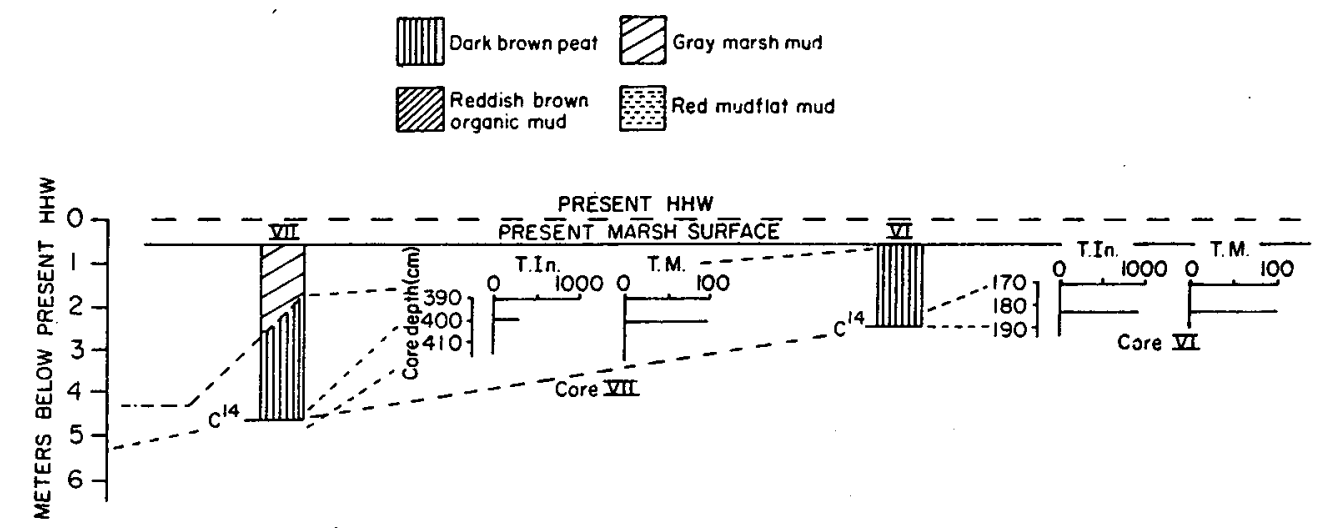

Fig. 13 - Lithologies and foraminiferal occurrences in Ft. Beausejour drill holes. Legend same as Figure 4.

amplification. Our oldest dates start at around $4000 \mathrm{ybp}$ and by this time tidal ranges were already $80 \%$ of present day ranges. The largest correction that must be made is $1.6 \mathrm{~m}$ $(20 \%$ of an $8 \mathrm{~m}$ amplitude) and in levels younger than 2500 ybp tidal amplification was $95 \%$ complete and corrections are only $0.4 \mathrm{~m}$ (Scott and Greenbert 1983). Hence, for the sealevel curves presented by Scott and Greenberg (1983), tidal amplification was a relatively minor contributor to the apparent sea-level rise, not onehalf of the apparent sea-level rise as suggested by Grant (1970).

\section{ACKNOWLEDGEMENTS}

T.E. Duffett, P. Lake, K. Jenner, A. Miller (Dalhousie), J. McLaughlin (NSERC, Atlantic Regional Laboratory) and A. Palmer (University of
South Carolina) all assisted in field operations. J. Barrett and T. Collins typed the manuscript and prepared the illustrations. Funding was provided by EMR research agreements and NSERC operating grants of Scott and Medioli. F. Gradstein and G. Vilks (Atlantic Geoscience Centre) kindly reviewed this paper.

Publication No. 17, Centre for Marine Geology, Dalhousie University.

\section{Systematic Taxonomy}

Species are listed here with their original reference only. All generic names are in accordance with Loeblich and Tappan (1964). All species are illustrated in Scott and Medioli (1980a)

Ammobaculites dilatatus Cushman and Bronnimann 
TABLE 3

Percentage occurences of Foraminifera along Transect II at Kingsport Station 1 is highest (above HHW). Station 2 is probably zone Ia, 3 and 4 are zone Ib, 5 and 6 are in zone Ila and all others are in zone Ilb.)

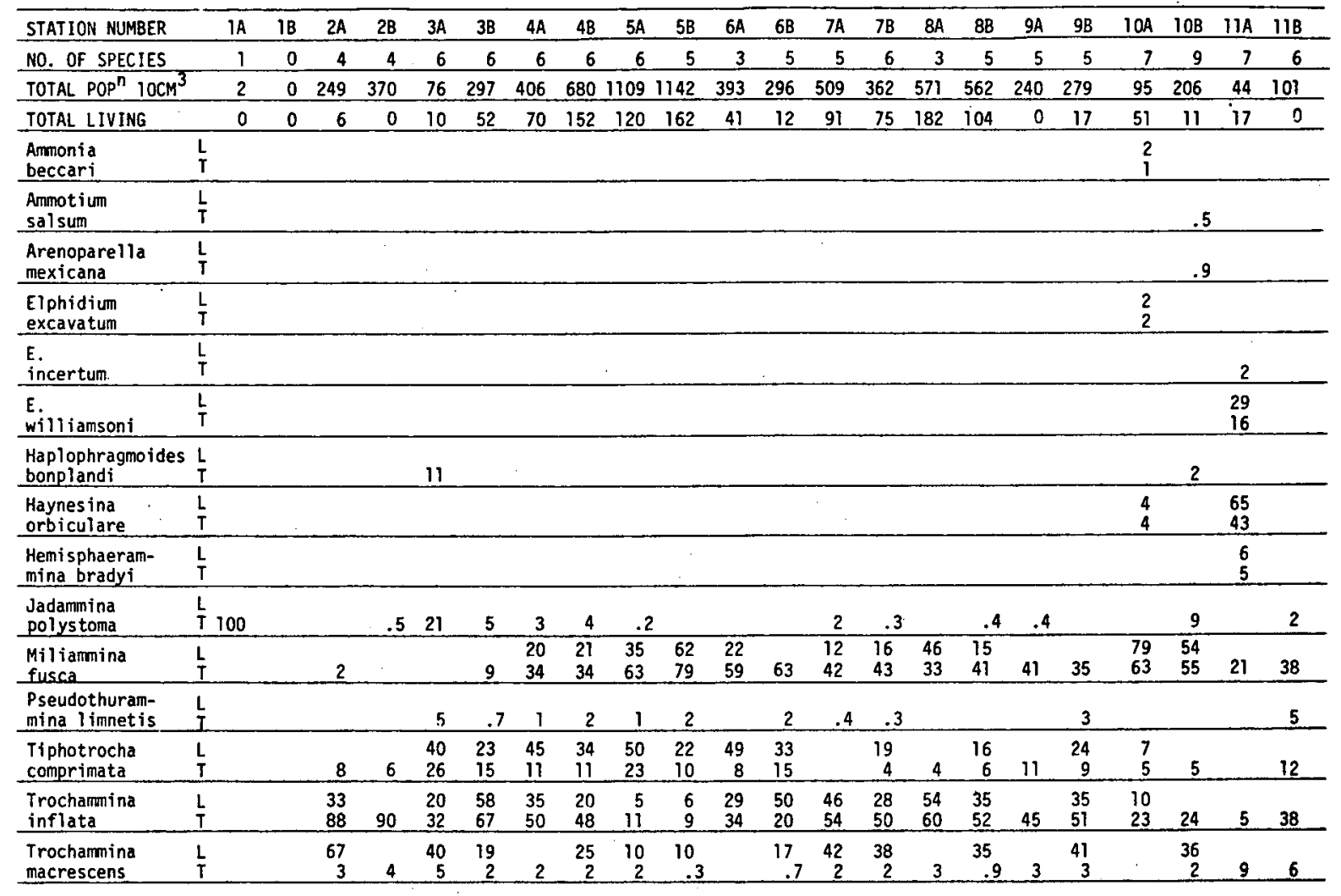

Ammobaculites dilatatus Cushman and Bronniman, 1948, p. 39, pl. 7, Figs. 10 , 11.

Ammobaculites foliaceus (H.B. Brady), Scott and Medioli 1980a, p. 35, pl. l, Figs. 6-8.

REMARKS - This species was originally referred to as A. foliaceus by Scott and Medioli but examination of type material by one of our students (C. Schroeder) proved this to be misidentified. What Scott and Medioli (1980a) refer to as A. dilatatus is probably A. exigus.

\section{Cibicides lobatulus \\ (Walker and Jacob)}

Nautilus lobatatus Walker and Jacob in Kanmacher 1798, p. 642, pl. 14, Fig. 36

\section{Elphidium excavatum} (Terquem)
Polystomella excavatum Terquem 1876, p. 429.

\section{Elphidium incertum (Williamson)}

Polystomella umbilicatula (Walker and Jacob) var. incerta, Williamson 1858 , p. 44, pl. 3, Fig. 82a.

\section{Haplophragmoides bonplandi}

(Todd and Bronnimann)

Haplophragmoides bonplandi Todd and Bronnimann 1957, p. 23, pl. 2, Fig. 2.

\section{Hemisphaerammina bradyi \\ (Loeblich and Tappan)}

Hemisphaerammina bradyi Loeblich and Tappan, in Loeblich and collaborators 1957, p. 224, pl. 72, Fig. 2. 
TABLE 4

Core locations, core depths, C-14 dates, Foram. zones, and sea-level corrections based on tidal amplification factors provided by Scott and Greenberg (1983). (Errors associated with foram. zone values are based on the vertical ranges of each zone.)

\begin{tabular}{|c|c|c|c|c|c|c|c|}
\hline Location & $\begin{array}{l}\text { Present day } \\
\text { tidal } \\
\text { amplitude }\end{array}$ & $\begin{array}{l}\text { Core No and } \\
\text { depth of sample } \\
\text { below HHW }\end{array}$ & $\begin{array}{c}\mathrm{C}^{14} \text { date } \\
\text { and Lab. No. }\end{array}$ & $\begin{array}{l}\text { Marsh } \\
\text { Foram. } \\
\text { Zone }\end{array}$ & $\begin{array}{l}\text { Apparent sea-level } \\
\text { rise with error }\end{array}$ & $\begin{array}{l}\quad \% \text { and actual } \\
\text { correction based on } \\
\text { tidal amplification }\end{array}$ & $\begin{array}{l}\text { True } \\
\text { relative } \\
\text { sea-level } \\
\text { rise }\end{array}$ \\
\hline $\begin{array}{c}\text { Kingsport } \\
" \\
"\end{array}$ & ${ }^{n} \mathrm{~m}$ & $\begin{array}{l}\text { Core III, } 4.5 \mathrm{~m} \\
\text { Core II, } 6.5 \mathrm{~m} \\
\text { Core I, } 9.5 \mathrm{~m}\end{array}$ & $\begin{array}{l}2355 \pm 180(G \times 6812) \\
2905 \pm 220 \quad(G \times 6811) \\
4430 \pm 215 \quad(G \times 6810)\end{array}$ & $\begin{array}{l}\text { Ib } \\
\text { Ia } \\
\text { Ia }\end{array}$ & $\begin{array}{l}4.2 \mathrm{~m} \pm .4 \mathrm{~m} \\
6.5 \mathrm{~m} \pm .1 \mathrm{~m} \\
9.5 \mathrm{~m} \pm .1 \mathrm{~m}\end{array}$ & $\begin{array}{c}5 \%, \quad .4 \mathrm{~m} \\
10 \%, .8 \mathrm{~m} \\
20 \%, 1.6 \mathrm{~m}\end{array}$ & $\begin{array}{l}3.8 \mathrm{~m} \\
5.7 \mathrm{~m} \\
7.9 \mathrm{~m}\end{array}$ \\
\hline $\begin{array}{c}\text { Granville Ferry } \\
\qquad \\
\vdots \\
-n\end{array}$ & $\begin{array}{l}5 \text { m } \\
n\end{array}$ & $\begin{array}{l}\text { Core III, } 3.9 \mathrm{~m} \\
\text { Core II, } 6.3 \mathrm{~m} \\
\text { Core I, } 10.14 \mathrm{~m}\end{array}$ & 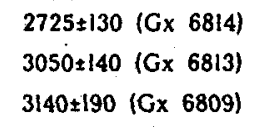 & $\begin{array}{l}\text { Ib } \\
\text { Ib } \\
\text { Ib }\end{array}$ & $\begin{array}{l}3.6 \mathrm{~m} \pm .4 \mathrm{~m} \\
6.0 \mathrm{~m} \pm .4 \mathrm{~m} \\
9.8 \mathrm{~m} \pm .4 \mathrm{~m}\end{array}$ & $\begin{array}{l}5 \%, .25 \mathrm{~m} \\
10 \%, .5 \mathrm{~m} \\
20 \%, 1.0 \mathrm{~m}\end{array}$ & $\begin{array}{l}3.35 \mathrm{~m} \\
5.5 \mathrm{~m} \\
8.8 \mathrm{~m}\end{array}$ \\
\hline $\begin{array}{c}\text { Mary's Point } \\
\text { " } \\
n \\
\text { " }\end{array}$ & $\begin{array}{l}n \\
n \\
\\
\therefore \\
n\end{array}$ & $\begin{array}{l}\text { Core II, } 3.5 \mathrm{~m} \\
\text { Core III, } 5.3 \mathrm{~m} \\
\text { Core V, } 6.2 \mathrm{~m} \\
\text { Core I, } 8.9 \mathrm{~m}\end{array}$ & $\begin{array}{l}2225 \pm 160(G \times 8146) \\
3130 \pm 180(G \times 8147) \\
3240 \pm 160(G \times 8148) \\
3640 \pm 180(G \times 8149)\end{array}$ & $\begin{array}{l}\text { Ia } \\
\text { Ib } \\
\text { la } \\
\text { Ib }\end{array}$ & $\begin{array}{l}3.5 \mathrm{~m} \pm .1 \mathrm{~m} \\
5.0 \mathrm{~m} \pm .4 \mathrm{~m} \\
6.2 \mathrm{~m} \pm .1 \mathrm{~m} \\
8.6 \mathrm{~m} \pm .4 \mathrm{~m}\end{array}$ & $\begin{array}{c}5 \%, .4 \mathrm{~m} \\
10 \%, .8 \mathrm{~m} \\
10 \%, \quad .8 \mathrm{~m} \\
20 \%, \quad 1.6 \mathrm{~m}\end{array}$ & $\begin{array}{l}3.1 \mathrm{~m} \\
4.2 \mathrm{~m} \\
5.4 \mathrm{~m} \\
7.0 \mathrm{~m}\end{array}$ \\
\hline $\begin{array}{c}\text { Ft. Beausejour } \\
n \\
n \\
n\end{array}$ & $\begin{array}{l}8 \mathrm{~m} \\
n \\
n \\
n\end{array}$ & $\begin{array}{l}\text { Core VI, } 2.3 \mathrm{~m} \\
\text { Core VII, } 4.4 \mathrm{~m} \\
\text { Core V!ll, } 6.2 \mathrm{~m} \\
\text { Core I, } 12.0 \mathrm{~m}\end{array}$ & 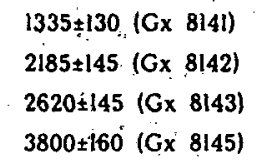 & $\begin{array}{l}\text { la } \\
\text { la } \\
\text { la } \\
\text { Ib }\end{array}$ & $\begin{array}{l}2.3 \mathrm{~m} \pm .1 \mathrm{~m} \\
4.4 \mathrm{~m} \pm .1 \mathrm{~m} \\
6.2 \mathrm{~m} \pm .1 \mathrm{~m} \\
11.8 \mathrm{~m} \pm .4 \mathrm{~m}\end{array}$ & $\begin{array}{c}5 \%, .4 \mathrm{~m} \\
5 \%, .4 \mathrm{~m} \\
5 \%, .4 \mathrm{~m} \\
20 \%, 1.6 \mathrm{~m}\end{array}$ & $\begin{array}{r}1.9 \mathrm{~m} \\
4.0 \mathrm{~m} \\
5.8 \mathrm{~m} \\
10.2 \mathrm{~m}\end{array}$ \\
\hline
\end{tabular}

Miliammina fusca (Brady)

Quinqueloculina fusca Brady 1870 , p. 47, pl. 1l, Figs. 2,3.

\section{Haynesina orbiculare (Brady)}

Nonionina orbiculare Brady 1881, p. 415 pl. 2l, Fig. 5 .

\section{Pseudothurammina limnetis (Scott and Medioli)}

Thurammina(?) limnetis Scott and Medioli 1980a, p. 43, 44, pl. l, Figs. 1-3.

\section{Tiphotrocha comprimata}

(Cushman and Bronnimann)

Trochammina comprimata Cushman and Bronnimann 1948, p. 41, pl. 8, Figs. 1-3.

\section{Trochammina inflata (Montagu)}

Nautilus inflata Montagu 1808, p. 81, pl. 18, Fig. 3.

\section{Trochammina macrescens}

(Brady)

forma polystoma

(Bartenstein and Brand)

Jadammina polystoma Bartenstein and Brand 1938, p. 381, Figs. la-c, 2a1.

BARTENSTEIN, H., and BRAND, E. 1938. Die Foraminiforan-Fauna des Jade-Gebietes I. Jadammina polystoma n.g., n. sp. aus dem Jade-Gebietes (for): Senckenbergiana, 20, pp. 381-385.

BRADY, H.B. 1870. In Brady, G.S. and Robertson, D. 1870. The ostracoda and foraminifera of tidal rivers with analysis and descriptions of foraminifera by H.B. Brady, part II. Annual Magazine of Natural History, 6, pp. 273-306.

CUSHMAN, J.A. and BRONNIMANN, P. 1948. Additional new species of arenaceous foraminifera from the shallow waters of Trinidad. Cushman Laboratory for Foraminiferal Research Contributions, 24, pp. 37-42.

DEONARINE, B. 1979. Foraminiferal distribution in two Nova Scotian marshes. Maritime Sediments, 15, pp. 35-46.

GRANT, D.R. 1970. Recent coastal submergence of the Maritime Provinces, Canada. Canadian Journal of Earth Sciences, 7, pp. 676-689.

GREGORY, M.R. 1970. Distribution of benthonic foraminifera in Halifax Harbour, Nova Scotia. Halifax, Dalhousie University, Ph.D. Thesis.

HARRISON, E.Z. and BLOOM, A.L. 1977. Sedimentation rates on tial salt marshes in Connecticut. Journal of Sedimentary Petrology, 47, pp. 1484-1490. 
KAYE, C.A. and BARGHORN, E.S. 1964. Late Quaternary sea-level change and crustal rise at Boston, Massachusetts, with notes on the autocompaction. of peat. Geological Society of America Bulletin, 75, pp. $63-80$.

LOEBLICH, A.R., Jr. and collaborators: TAPPAN, H., BECKMAN, J.P., BOLLl, H.M., GALLITELLI, E.M., TROELSEN, J.C. 1957. Studies in Foraminifera. U.S. National Museum Bulletin 215, 321p.

LOEBLICH, A.R., Jr. and TAPPAN, H. 1964. Sarodina, chiefly "Thecamoebians" and Foraminiferida, in Moore, R.C. ed., Treatise on Invertebrate Paleontology, Protista 2, pt. C, Kansas University Press, 1,2, 899p.

MONTAGU, G. 1808. Testacea Britannica, supplement. Exeter, England, S. Woolmer, 183p.

PETRUCCI, F., MEDIOLI, F.S., SCOTT, D.B., PIANETTI, F.A. and CAVAZZINI, R. 1983. Evaluation of the usefulness of foraminifera as sea level indicators in the Venice Lagoon. Acta Naturalia de l'Ateneo Parmense, 19, pp. 63-77.

SCOTT, D.B. 1976. Quantitative studies of marsh foraminifera patterns in southern California and their application to Holocene stratigraphic problems. First International Symposium on Benthonic Foraminifera of Continental Margins, Part A, Ecology and Biology, Maritime Sediments, Special Publication 1, pp. 153-170.

SCOTT, D.B. 1977. Distribution and population dynamics of marsh-estuarine foraminifera with applications to relocating Holocene sea levels. Dalhousie University, Halifax, Ph.D. dissertation, 252p.

SCOTT, D.B. and MEDIOLI, F.S. 1978. Vertical zonations of marsh foraminifera as accurate indicators of former sea levels. Nature, 272, pp. 528-531.
SCOTT, D.B. and MEDIOLI, F.S. 1980a, Quantitative studies of marsh foraminifera distributions in Nova Scotia: implications for sea-level studies. Cushman Foundation for Foraminiferal Research, Special Publication no. $17,58 \mathrm{p}$.

SCOTT, D.B. and MEDIOLI, F.S. 1980b. Living vs. total foraminifera populations: their relative usefulness in paleoecology. Journal of Paleontology, 54, pp. 814-831.

SCOTT, D.B., WILLIAMSON, M.A. and DUFFETT, T.E. 1981. Marsh foraminifera of Prince Edward Island: their recent distribution and application for former sea lével studies. Maritime Sediments and Atlantic Geology, 17, pp. 98-129.

SCOTT, D.B. and GREENBERG, D.A. 1983. Relative sea-level rise and tidal development in the Fundy tidal system. Canadian Journal of Earth Sciences, 20 , pp. $1554-1564$.

TERQUEM; O. 1876. Essai sur le classement des animaux qui vivent sur la plage et dans les environs de Dunkerque: Premiere partie. Societe Dunderquoise; Memoires, 19, (1874-75), pp. 405-457.

TODD, R. and BRONNIMANN, P. 1957. Recent foraminifera and thecamoebina from the Eastern Gulf of Paria. Cushman . Foundation for Foraminiferal Research, Special Publication 3, 43p.

WALKER, G. and JACOB, E. 1798. In Kanmacher, Adam's Essays on the microscope, Ed. 2, London.

WILLIAMSON, W.C. 1858. On recent foraminifera of Great. Britain. Royal Society (London) Publication, 107p. 